\title{
The Kock Fault Zone as an indicator of tectonic stress regime changes at the margin of the East European Craton (Poland)
}

\author{
Maciej TOMASZCZYK ${ }^{1, *}$ and Marek JAROSIŃSKI ${ }^{2}$ \\ 1 Polish Gas and Oil Company SA, Kasprzaka 25, 01-224 Warszawa, Poland \\ 2 Polish Geological Institute - National Research Institute, Rakowiecka 4, 00-975 Warszawa, Poland
}

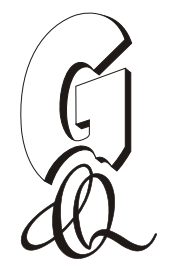

Tomaszczyk, M., Jarosiński, M., 2017. The Kock Fault Zone as an indicator of tectonic stress regime changes at the margin of the East European Craton (Poland). Geological Quarterly, 61 (4): 908-925, doi: 10.7306/gq.1380

\begin{abstract}
Integrated tectonic interpretation of seismic data and core samples from boreholes in the vicinity of the Kock Fault Zone (KFZ) allowed us to identify several tectonic deformation events that were responsible for creating its complex structure. The KFZ is an example of a mechanically weak regional-scale tectonic structure that accumulated deformation over hundreds of millions of years and therefore is a good indicator of stress regime changes in a broader area. The KFZ is here regarded as a combination and superposition of two genetically and temporally different faults: the older Kock Fault, which is an inverted normal fault, and the younger, low-angle Kock Thrust. The first, Silurian stage of KFZ evolution occurred in a tensional stress regime that gave rise to the activation of a deeply rooted normal-slip precursor to the Kock Fault. Subsequently, this fault underwent inversion during the Late Famennian compressive/transpressive event. In the Early Carboniferous, the tectonic stress regime changed into tension/transtension, leading to extrusion of basalt magma and abundant mineralisation in the vicinity of the inverted Kock Fault, followed by tectonically relaxed sedimentation of Carboniferous strata. The deposition was terminated by a compressional event at the end of the Westphalian. Contraction resulted in the formation of the low-angle Kock Thrust decoupled in Silurian shale that cut across the upper part of the Kock Fault and displaced it towards the NE, over the East European Craton foreland.
\end{abstract}

Key words: tectonics, seismic interpretation, borehole core analysis, Kock Fault Zone, Lublin Basin.

\section{INTRODUCTION}

The Kock Fault Zone (KFZ) is an important tectonic boundary within the Lublin Basin, located at the edge of the East European Craton (EEC). During Early Paleozoic times, the study area was a marginal portion of the Baltica plate occupied by the proximal part of the foreland basin involved in the Caledonian collision with Avalonia (Poprawa, 2006). During the Variscan Orogeny, the subsidence of the Lublin Basin developed in response to the multiphase collision occurring in the inner part of the Variscan belt. In our opinion, the present state of knowledge allows presenting a regional plate-tectonic background to the tectonic setting of the KFZ, as the original position of the Variscan collision zone with respect to the Lublin Basin is still unknown and probably far from the present-day arrangement. Separation of collision and foreland regions by the Teisseyre-Tornquist Zone (TTZ), which is a major lithospheric shear zone prone to strike-slip motions both in Caledonian (Brochwicz-Lewiński et al., 1981) and Variscan times (Lewandowski, 1992), would make this reconstruction difficult and still unreliable. The mechanism of Variscan subsidence at the edge of Baltica and within the Lublin Basin and the role of main faults bounding and transecting the Lublin Basin

\footnotetext{
* Corresponding author, e-mail: maciej.tomaszczyk@gmail.com
}

Received: June 5, 2017; accepted: August 16, 2017; first published online: September 14, 2017 are still a matter of discussion (Narkiewicz et al., 1998). We are still at the stage of gathering structural data and kinematic interpretations to bring the elements of the recent structural patchwork to their original position in the Caledonian and Variscan plate accretion scenario. The KFZ, which controlled the subsidence pattern in the sedimentary basin and the shape of the finite tectonic structure of the area, seems to be an important part of such a reconstruction.

The NW-SE trending, $160 \mathrm{~km}$ long KFZ extends along the marginal part of the EEC in central-eastern Poland (Fig. 1) within the Late Paleozoic Lublin Basin (Fig. 2). According to the most recent interpretations regarding the position of the front of the Variscan Orogen in Poland (Aleksandrowski and Buła, 2017; Krzywiec et al., 2017) the KFZ represents a local boundary between the folded and thrusted and undeformed parts of the Variscan foreland (Fig. 1). The KFZ defines also the boundary between the two structural elements of the Lublin Basin: Lublin Synclinorium and Hrubieszów High (Figs. 1 and 2), (Żelichowski, 1972; Narkiewicz and Dadlez, 2008). We regard this zone to be a combination and superposition of two genetically and temporally different faults: the older Kock Fault, which is an inverted normal fault, and the overprinted, younger, low-angle Kock Thrust. The KFZ has a character of sustained crustal-scale weakness zone, highly sensitive to stress regime changes. Active until the Cenozoic, this zone bears a record of numerous tectonic events. We assumed that focusing our research on a single, multiphase tectonic structure might give even a better resolution of tectonic evolution than a more regionally extensive, basin-scale study. The main disadvantage 


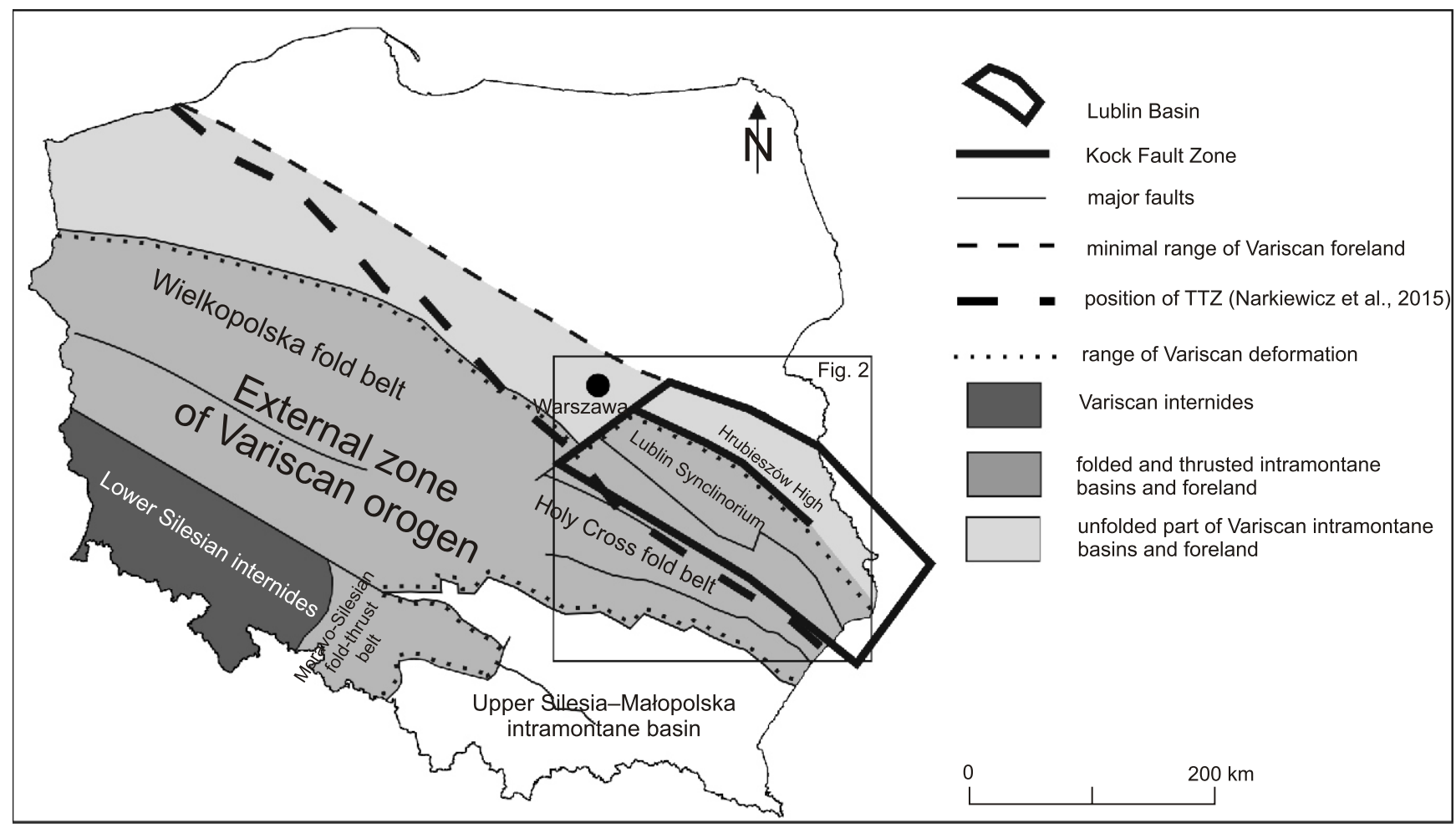

Fig. 1. Location of the Kock Fault Zone on the Variscan structure map of Poland (after Aleksandrowski and Buła, 2017, simplified)

arising from such an approach is the cumulating of deformations and the overprint of a great number of tectonic deformations in a narrow tectonic zone, which obliterate the record of the earlier phases.

Although the KFZ has attracted attention of geologists for a couple of decades, there is still lack of consensus regarding a genetically and kinematically consistent model of its evolution. Over the last 50 years, several tectonic models have been developed concerning the evolution of the whole Lublin Basin. In our opinion, previously published concepts of the KFZ do not address the long and complex structural evolution of its tectonic structure sufficiently. This article aims to fill this gap by genetically coherent tectonic interpretation of a large number of seismic profiles and core samples. Due to significant improvement in the quality of seismic imaging and processing, which has taken place in the past several years, and the concentration of geological surveys in the vicinity of KFZ, the reconstruction of multi-phase tectonic evolution of this zone became possible. This also sheds the light on tectonic history of the Lublin Basin. Since the Lublin Basin is an area of conventional and unconventional hydrocarbons exploration, such a synthesis is also important from the oil industry point of view. The geometry of tectonic deformation controlling the fracture network pattern, together with the concept of structural evolution, is an important element of both reservoir quality assessment and design of directional and horizontal boreholes for stimulation of production.

\section{GEOLOGICAL SETTING}

For the first time, the KFZ was described by Żelichowski (1972) as the North-east Fault (Czersk-Żelechów-Kock-Wasylów), separating the Lublin Synclinorium from the elevated part of the East European Craton, the so-called Hrubieszów High. The KFZ terminates in the NW direction as far as the transversal Grójec Fault (Żelichowski, 1972; Żelichowski and
Kozłowski, 1983; Pożaryski and Dembowski, 1983; Fig. 2). In its SE segment, the KFZ gradually expires and terminates on approaching the Święcica Fault. On the sub-Carboniferous geological maps, this zone represents a sharp boundary between the late Devonian complex of the Lublin Synclinorium and the Silurian and Devonian of the Hrubieszów High (Fig. 3). In turn, on the sub-Permo-Mesozoic geological maps, the KFZ is marked as a narrow strip of Devonian and Silurian rocks exposed at the Carboniferous subcrop (Żelichowski, 1972; Żelichowski and Kozłowski, 1983; Pożaryski and Dembowski, 1983; Fig. 2). The maximum width of this Devonian and Silurian strip is $6 \mathrm{~km}$ in the central segment of the KFZ, and it decreases gradually in both directions.

Initially, the KFZ was considered to represent a horst limited by steep normal faults (Żelichowski, 1972; Żelichowski and Kozłowski, 1983; Dembowski and Porzycki, 1988; Pożaryski and Tomczyk, 1993; Fig. 4A). Pelc (1999) interpreted this zone as a result of the diapiric deformation of incompetent Silurian shale above deep-rooted reverse faults (Fig. 4B). A different concept by Antonowicz et al. (2003) explained the KFZ structure as a stack of thrust units creating a duplex within a triangle zone (Fig. 4C). Subsequently, Antonowicz and Iwanowska (2004) reduced this duplex to a single NE-verging thrust that displaced the Upper Paleozoic deposits of the Lublin Synclinorium onto the Hrubieszów High block. Krzywiec $(2007,2009,2011)$ linked the geometry of KFZ with the presence of contractional deformation (thrusts) developed above the reverse fault with simultaneous quasi-diapiric ductile deformation of Silurian shale (Fig. 4D). A new tectonic model presented by Kufrasa and Krzywiec (2015) and Krzywiec et al. (2017) adopted the idea of ductile duplexes (Thomas, 2001) developed for the Appalachians, for the Silurian complex over the Kock Fault.

According to our interpretation, the KFZ structure changes in the vertical profile due to superposition of several faults. The NE boundary of the KFZ is marked by the Kock Thrust that emplaced older rocks on top of the Carboniferous complex. The 


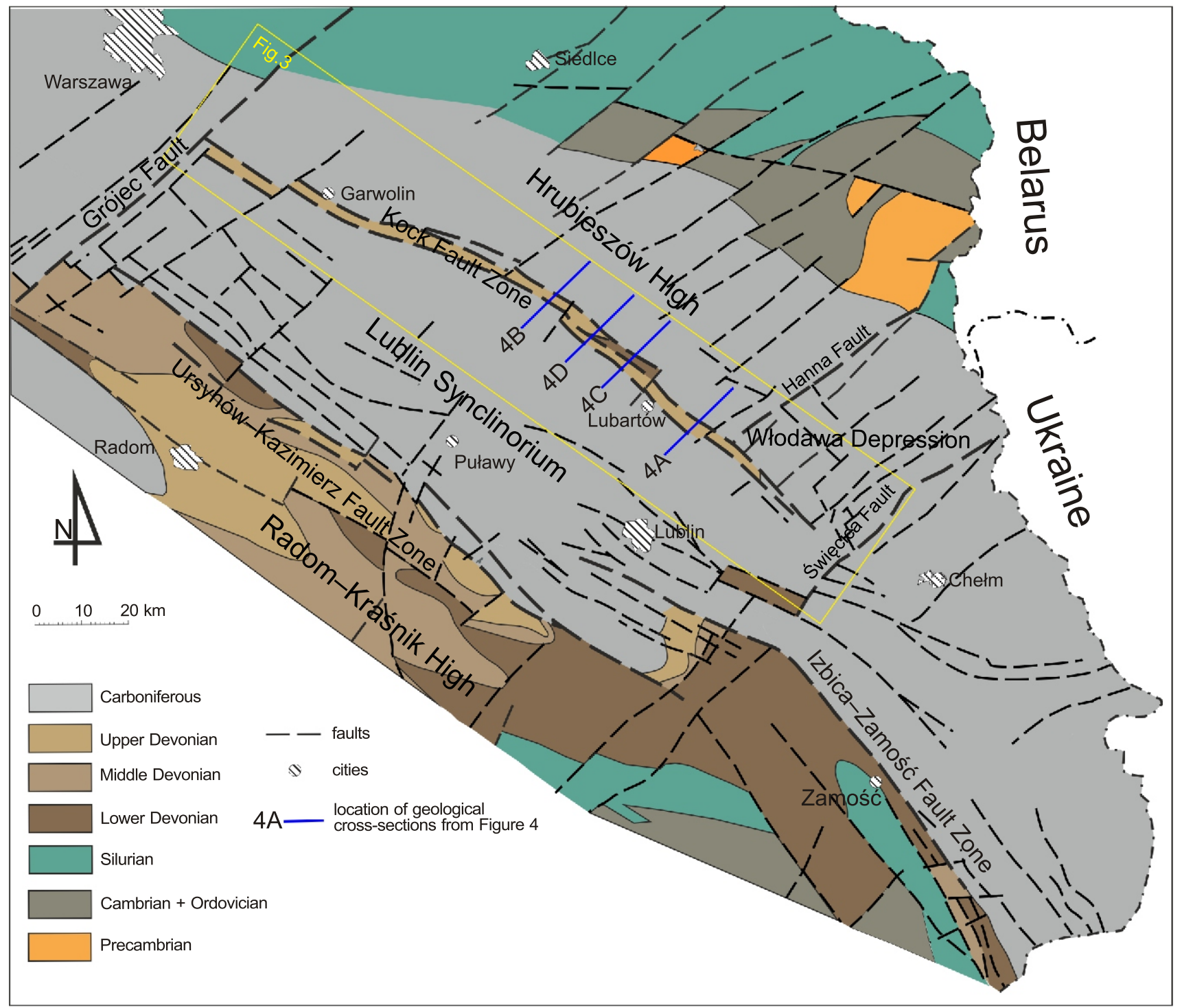

Fig. 2. Geological map of the Lublin Basin without the Cenozoic and Permo-Mesozoic cover

(after Żelichowski and Kozłowski, 1983, simplified and modified)

Blue lines indicate position of schematic cross-sections through the KFZ, presented in Figure 4

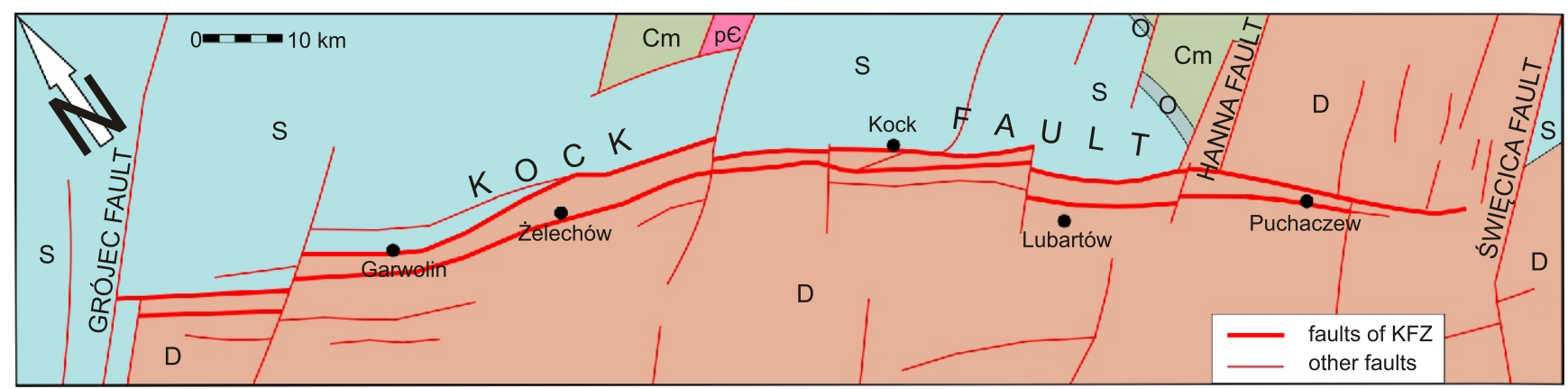

Fig. 3. Sub-Carboniferous geological map of the Kock Fault Zone area (after Żelichowski and Kozłowski, 1983, simplified and modified)

$\mathrm{p} €$ - Precambrian, Cm - Cambrian, O - Ordovician, S - Silurian, D - Devonian 


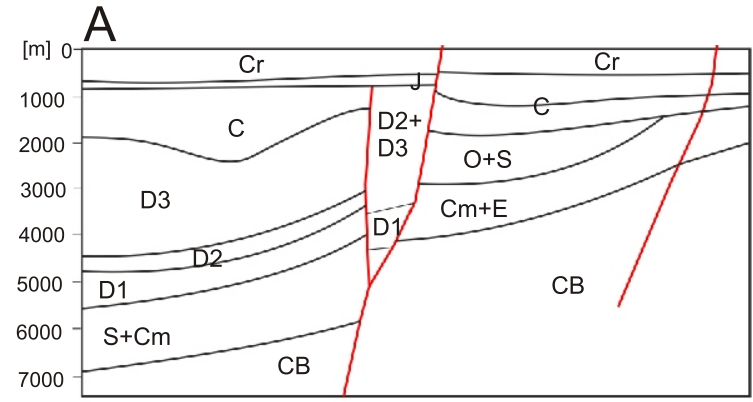

$$
\text { B }
$$
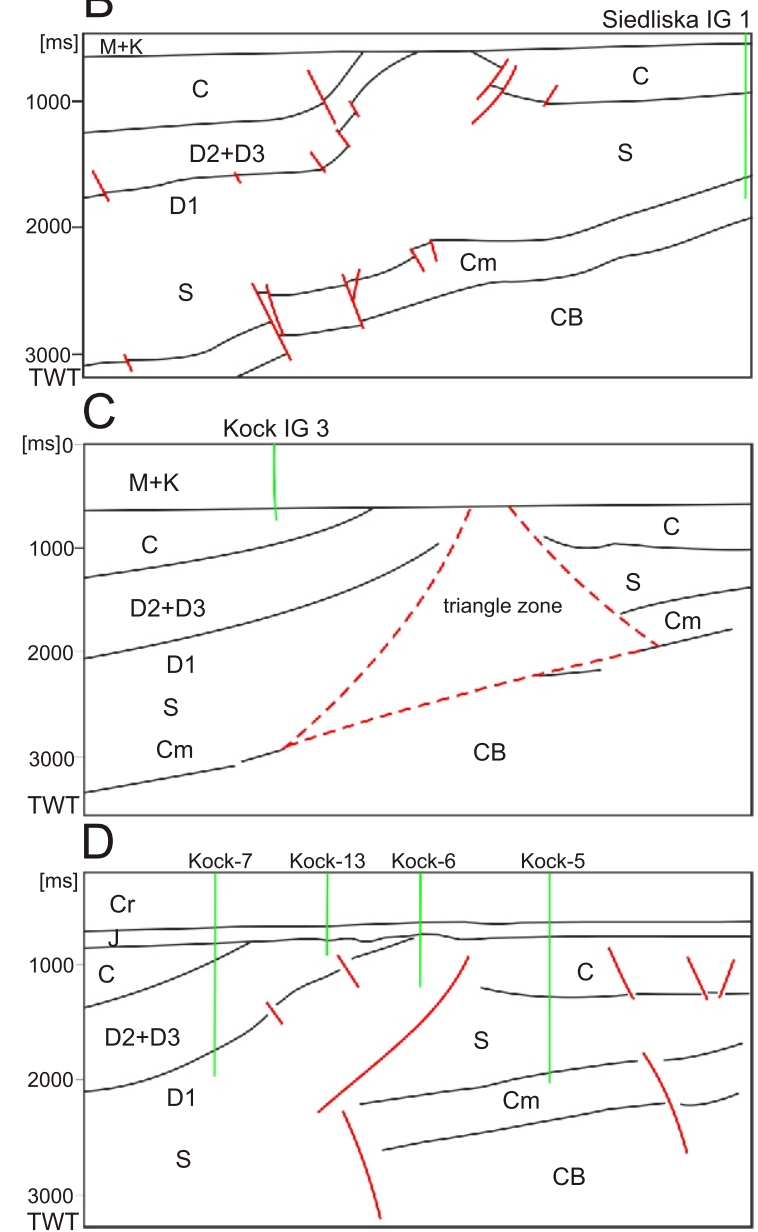

Fig. 4. Previous interpretations of the Kock Fault Zone on simplified cross-sections by: A - Żelichowski and Kozłowski, (1983); B - Pelc (1999); C - Antonowicz et al. (2003); D Krzywiec (2009), graphically unified

CB - crystaline basement, Cm - Cambrian, O - Ordovician, E Ediacaran , S - Silurian, D1 - Lower Devonian, D2 - Middle Devonian, D - Upper Devonian, C - Carboniferous, J - Jurassic, $\mathrm{Cr}$ Cretaceous, $\mathrm{M}+\mathrm{K}$ - Mesozoic + Cenozoic; location of cross-sections is shown in Figure 2

SW boundary is formed by a homocline dipping to the SSW towards the Lublin Synclinorium, and by a set of SSW-verging thrusts. As the horizontal range of the KFZ at the upper level is defined by a wide belt of thin-skinned tectonic features, at the deeper structural levels this zone narrows to single leading fault zone. The depth to the crystalline basement varies across the KFZ due to both regional SW dipping of the basement and a crustal discontinuity associated with this zone. At the Hrubieszów High near the KFZ the depth to the crystalline basement is $<5.5 \mathrm{~km}$, whereas on the other side of this zone, below the Lublin Synclinorium, the top of the basement occurs 0.5 to $2 \mathrm{~km}$ deeper. A step-like depth change is visible in both seismic profiles and the Bouguer gravity map (Królikowski and Petecki, 1995). In the Lublin Synclinorium, filled with a thick sedimentary cover, the most reliable data on the top of the basement are provided by seimic surveys due to the lack of boreholes reaching the crystalline basement.

The oldest sedimentary rocks in the vicinity of KFZ are coarse-grained clastics deposited in the Ediacaran rift. They are overlain with the Upper and Middle Cambrian clastic succession (Pacześna, 2006). While on the Hrubieszów High those Ediacaran-Cambrian deposits have been reached by boreholes (Pacześna, 2006, 2010), their presence in the Lublin Synclinorium is interpreted only from seismic profiles. Between the Cambrian and Ordovician, an erosional gap is observed, which spans the Late Cambrian and locally the earliest Ordovician (Tremadocian). Late Ordovician to Late Devonian deposition was continuous (Narkiewicz et al., 2007). The thickness of the Ordovician, represented mostly by carbonates, does not exceed $100 \mathrm{~m}$. The thicknesses of Silurian siltstones/mudstones are different on both sides of the KFZ (Fig. 5). In some parts of the Hrubieszów High, the thickness of the Silurian is more than twice that in the Lublin Synclinorium. The Lower Devonian comprises $\sim 1000 \mathrm{~m}$ of shales and clastic deposits (Fig. 5). The Middle Devonian with a thickness of $<200 \mathrm{~m}$ is represented by carbonates and clastics (Fig. 5). The Upper Devonian is represented by marine carbonates and marls (Fig. 5). In the most upper part of profile, they pass into shallow marine and terrestrial clastics (Narkiewicz, 2011). This change in sedimentation can be linked with syndepositional activity of the Kock Fault. South-east of the KFZ, the thickness of the Upper Devonian complex is $<2000 \mathrm{~m}$ and decreases towards the NW. Due to the Late Devonian/Early Carboniferous uplift of the Hrubieszów High the Devonian is completely removed by erosion, except in the downdropped Włodawa Depression (part of the Hrubieszów High) where the Upper Devonian succession has been preserved (Fig. 4). In the case of the most intense uplift, part of the Silurian complex has also been eroded.

The Carboniferous sedimentation was preceded by basaltic volcanism accompanied by deposition of pyroclastic rocks which were found in boreholes drilled within and north-east of the KFZ. In the vicinity of this zone, the youngest Carboniferous deposits are of Middle Visean (Fig. 5; Żelichowski, 1972, 1984; Narkiewicz et al., 2007) or Westphalian (Bashkirian) age (Żelichowski, 1972; Żelichowski and Kozłowski, 1983). The Carboniferous sedimentary complex consists of claystones, mudstones, siltstones and coal seams, with the combined original thickness estimated at $1500-2000 \mathrm{~m}$ close to the KFZ (Fig. 5). The erosional top of this complex is covered by Permian or Permo-Mesozoic rocks in the NW segment, or directly by the Mesozoic in the rest of KFZ. The Mesozoic cover starts either with the Middle Jurassic in the SE segment of the KFZ or with the Triassic in the central and NW segments, and terminates with the Upper Cretaceous. Cenozoic deposits are completely eroded in the eastern segment and partly in the central segment of KFZ. The combined thickness of the Permian, Mesozoic and Cenozoic deposits varies between 800 and $1000 \mathrm{~m}$ in the eastern and central segments and reaches $3000 \mathrm{~m}$ in the western segment of KFZ. 

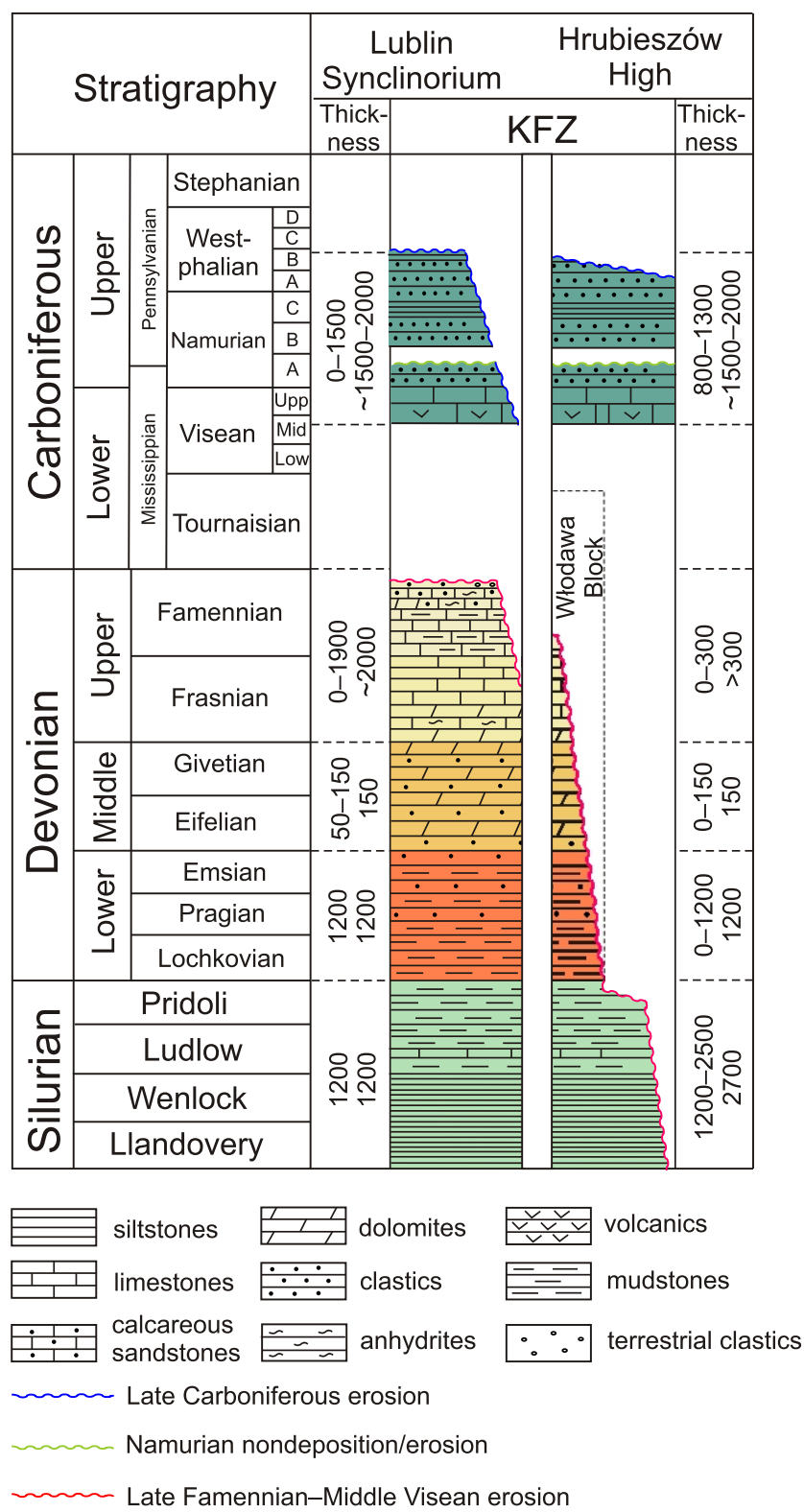

1200-2500 present thickness

2700 maximum original thickness

Fig. 5. Schematic lithostratigraphic profiles of the study area, showing sedimentary changes across the Kock Fault Zone

\section{GEOLOGICAL AND GEOPHYSICAL DATA}

Our analysis covered more than 150 seismic profiles from the KFZ area. About 80 profiles are of best quality, but only 7 of them are presented in this paper (Figs. 6-8). Interpretation of these 7 profiles in terms of geometry and kinematics of tectonic deformation is consistent with the rest of analysed profiles. While adjacent to the KFZ, geometry of the sedimentary complex is well visible in the seismic image, the internal structure of this zone is typically characterized by a homogeneous record which does not allow for more detailed interpretation. Most of the seismic sections were available in a depth domain, which helps in controlling the tectonic structure geometry. In addition, we used some detailed gravity maps (Ostrowski and Musiatewicz, 1996; Wójcicki et al., 1998) for fault correlation between seismic profiles, especially in areas where seismic data coverage is poor.

A structural study of well-preserved drill cores was performed for 5 boreholes drilled within and adjacent to the KFZ. These historical boreholes from the 1960s and 1990s lack modern geophysical well logs, therefore geophysics would not support core orientation or other aspects of tectonic interpretation. Because of this, we have used the method of indirect core orientation relative to dip of bedding, which we assume to match the dip revealed by seismic profiles. Although such an approach may help in general recognition of structural trends, one should bear in mind that the orientation is hypothetical and prone to significant error. Therefore, in the description of a strike or trend of tectonic structures we prefer to use general terms like "longitudinal", "transversal" or "oblique" to the strike of the hosting strata, instead of trying to guess the exact azimuth angle. Scanty coring is another important limitation in our analysis and the reason why the results of structural interpretations are hardly comparable among boreholes, at least in their quantitative aspects. In historical boreholes, core intervals taken in a single run of the $9 \mathrm{~m}$ long drill string are often separated from each other by several tens of metres. In the case of investigated boreholes, the cored sections cover from several to $90 \%$ of the analysed interval.

\section{STRUCTURAL INTERPRETATION OF SEISMIC DATA}

For the entire study area, we have attempted to interpret six horizons in the Paleozoic complex. Two of them representing Late Paleozoic unconformities are well visible in each seismic profile: (1) base-Permian unconformity, (2) base-Visean unconformity, (3) Middle Devonian marker, (4) near top-Silurian marker, (5) top-Ordovician-Cambrian, and (6) top of the crystalline basement.

Based on seismic interpretation, two main structural features have been distinguished in the KFZ: the Kock Fault, deep-rooted in the crystalline basement, and the Kock Thrust being a primary low-angle, north-verging fault among a set of secondary contractional thin-skinned deformations. These thin-skinned structures cut across and displaced the older Kock Fault and associated structures.

\section{THE STRUCTURE OF THE KOCK FAULT}

In seismic sections, the Kock Fault is recognized in the eastern and central parts of the KFZ, while in the western segment it is not recorded due to low quality of seismic data. The Kock Fault is interpreted as a single structural discontinuity dipping $50-60^{\circ}$ towards the NE (Figs. 6-8A). Due to a complex reactivation there are some secondary faults branching off the Kock Fault (Figs. 7 and 8). Looking at the present-day geometry of the fault, one should consider that the sense of its offset changed during the fault's evolution. At the deepest level, this fault is visible as a dislocation throws down the top of the crystalline basement several hundred metres towards the SW (Figs. 6 and 7).

The first stage of the Kock Fault displacement, which is visible on seismic profiles, is represented by significant differences in the Silurian thickness on both sides of the Kock Fault in the central part of KFZ (Figs. 6A, B and 7). Although the Silurian complex of the Hrubieszów High (NE of the Kock Fault) under- 

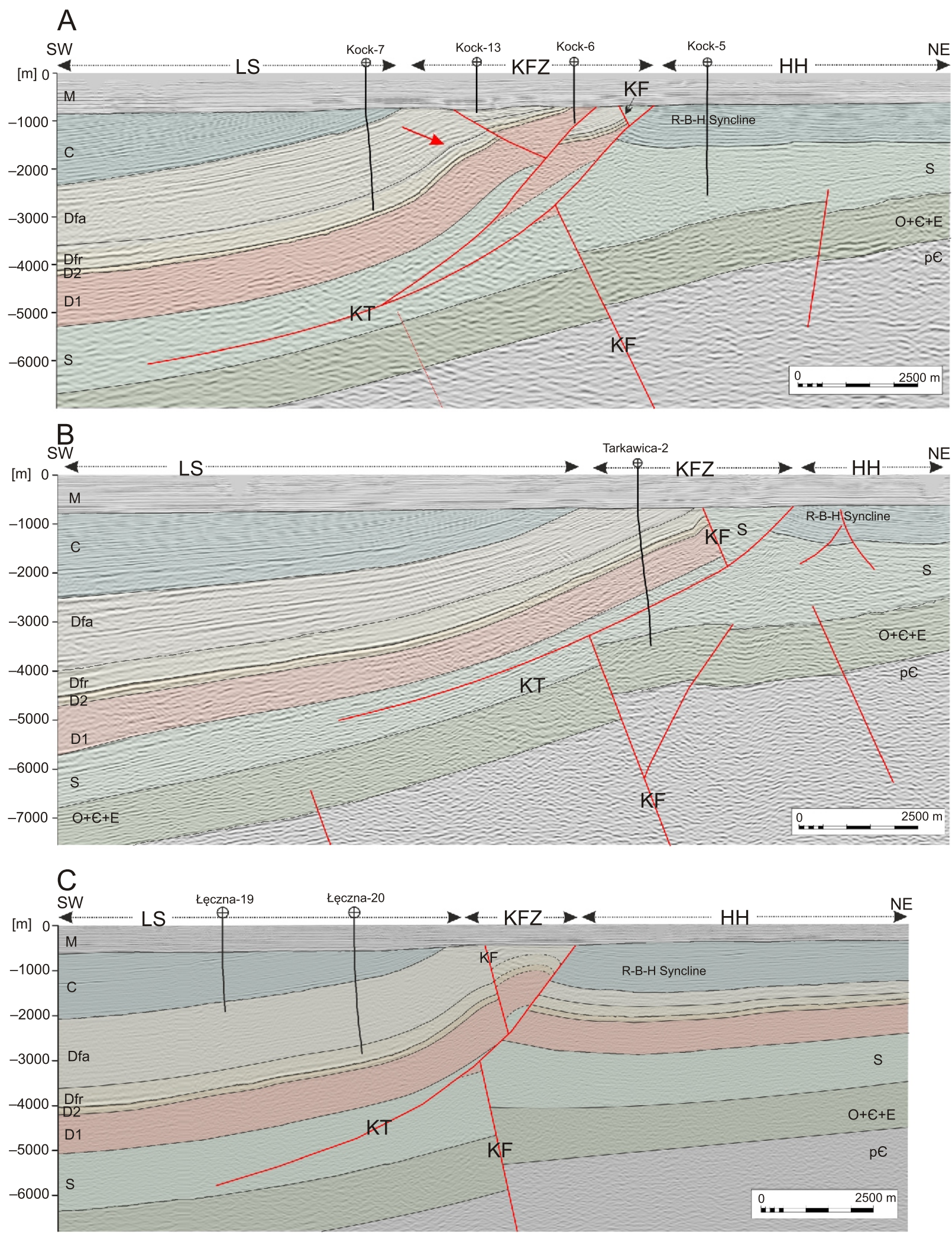

Fig. 6. Interpretation of seismic profiles across the Kock Fault Zone, KFZ (for location see Fig. 9)

A - seismic profile T0010479 from the central segment of KFZ; arrow points to the Frasnian thickness decrease towards the KFZ B - seismic profile T020405 from the central segment of KFZ; arrow points to the fault drag of Devonian strata in the footwall of the Kock Fault; C - seismic profile T010205 from the central segment of KFZ; arrow shows interpreted $1 \mathrm{~km}$ displacement of the Kock Fault by the younger Kock Thrust; HH - Hrubieszów High, KF - Kock Fault, KFZ - Kock Fault Zone, KT - Kock Thrust, LS - Lublin Synclinorium, RBH - Radzyń-Bogdanka-Chełm; $\mathrm{p} €$ - Precambrian, $\mathrm{O}+€+E-$ Ordovician + Cambrian + Ediacaran, $S-S i l u r i a n$, D1 - Lower Devonian, D2 - Middle Devonian, Dfr - Upper Devonian (Frasnian), Dfa - Upper Devonian (Famennian), C - Carboniferous, $\mathrm{M}$ - mostly Mesozoic (younger than Carboniferous) 

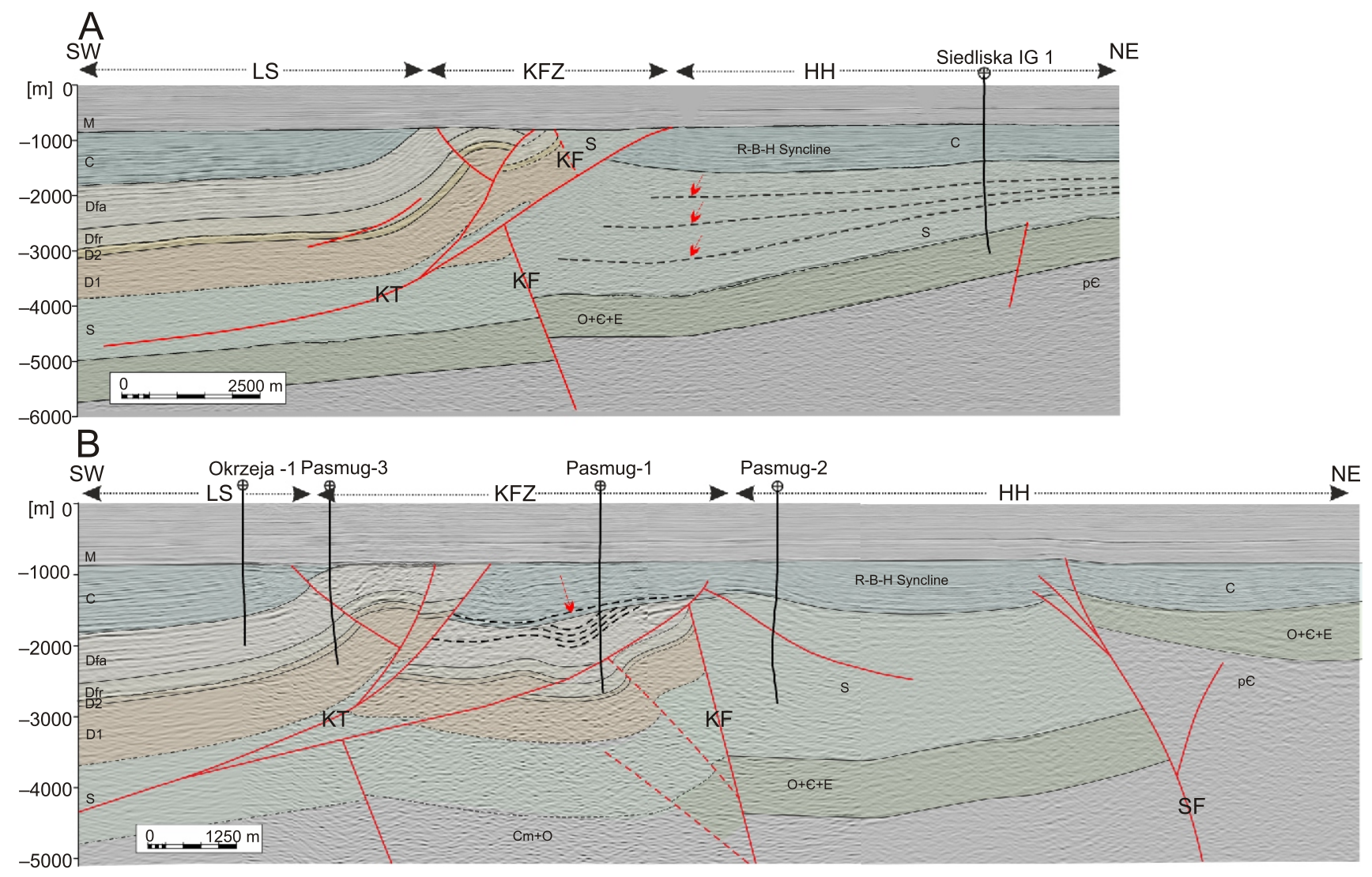

Fig. 7. Interpretation of seismic profiles across the Kock Fault Zone, KFZ (for location see Fig. 9)

A - seismic profile T0060494 from the central segment of KFZ, arrows point to syndepositional unconformities in the Silurian complex; B - composite seismic profile T0110485, T020491, T0210494 and K050198 from the central segment of KFZ; arrow points to unconformity between folded, steeply-dipping (up to $40^{\circ}$ ) Devonian and overlaying gently-tilted Carboniferous strata; explanations as in Figure 6

went partial erosion in Late Famennian-Middle Visean times (Żelichowski, 1972; Żelichowski and Kozłowski, 1983), its thickness here is more than twice of that in the Lublin Synclinorium. This thickness increases towards the Kock Fault and reaches its maximum immediately next to the fault, indicating its syndepositional activity in the Silurian. Both the relation between the fault dip direction and the trend of thickness growth and the pinch-out of seismic reflectors prove normal fault kinematics of the Kock Fault in the Silurian. Growth strata visible in the intra-Silurian seismic reflection pattern (marked with red arrows in Fig. 7A) confirm an extensional roll-over kinematics of the Kock Fault's hanging wall. An original displacement in the Late Silurian (observed in the central segment of this fault) reached as much as $2000 \mathrm{~m}$. In the marginal segment, SE of the Hanna Fault (striking perpendicular to the Kock Fault (Fig. 2), the thickness of the Silurian section changes significantly across the Kock Fault (Fig. 6C), indicating dying out of this fault during the Silurian.

In the Late Famennian, the Kock Fault underwent inversion that resulted in the uplift and erosion of its NE hanging wall - the Hrubieszów High. Close to the Kock Fault, the maximum erosion interpreted from the missing Devonian-Tournaisian section is up to $2500 \mathrm{~m}$ (Fig. 7A). Other authors estimate the range of erosion at $1500 \mathrm{~m}$ (Narkiewicz, 2007) or $2000 \mathrm{~m}$ (Żelichowski, 1972). The Devonian and partially Silurian deposits were eroded over the Hrubieszów High, except in the Włodawa Depression, located between the Hanna and Święcica faults (Żelichowski and Kozłowski, 1983; Figs. 2 and $6 C)$, where only the Upper Devonian complex is reduced close to the Kock Fault. At some isolated places of the Hrubieszów High, e.g. the Tarkawica-1 borehole, or probably west of the Pasmug-2 borehole, the Lower Devonian section has been partly preserved, although significantly reduced as well.

The inversion of the Kock Fault and the related erosion of the Hrubieszów High triggered a change in the Late Famennian sedimentation pattern in the NE flank of the Lublin Synclinorium, also reported by other authors (Miłaczewski and Żelichowski, 1968; Żelichowski, 1972), where shelf carbonates were replaced by shallow-marine siliciclastic deposits. In the latemost Famennian, terrestrial sedimentation also took place in the direct vicinity of the Kock Fault (Narkiewicz, 2011). At the Hrubieszów High, a minor angular unconformity between the Silurian and the overlying Carboniferous complex is visible in the central segment of the KFZ (Figs. 6 and 7), indicating a rigid behaviour of this block during the Late Famennian-Middle Visean tectonic phase. The increased thickness of Famennian deposits in the Pasmug-1 borehole is related to a high dip of strata (up to $40^{\circ}$ ), which is also observed in the seismic profile where tilted reflectors related to the Famennian complex truncate at the angular unconformity (marked with arrows in Fig. 7B). In our opinion, this local homoclinal inclination of Late Devonian strata is a result of the Kock Fault propagation upwards during Late Famennian inversion. Structural interpretation of the core data from the Kock IG 1 borehole located within the Kock Fault (described in the next section) suggests that the Silurian and Lower Devonian strata had already been inclined before they were cut by the low-angle thrust. The tilting of the strata might have resulted from the Late Famennian inversion 

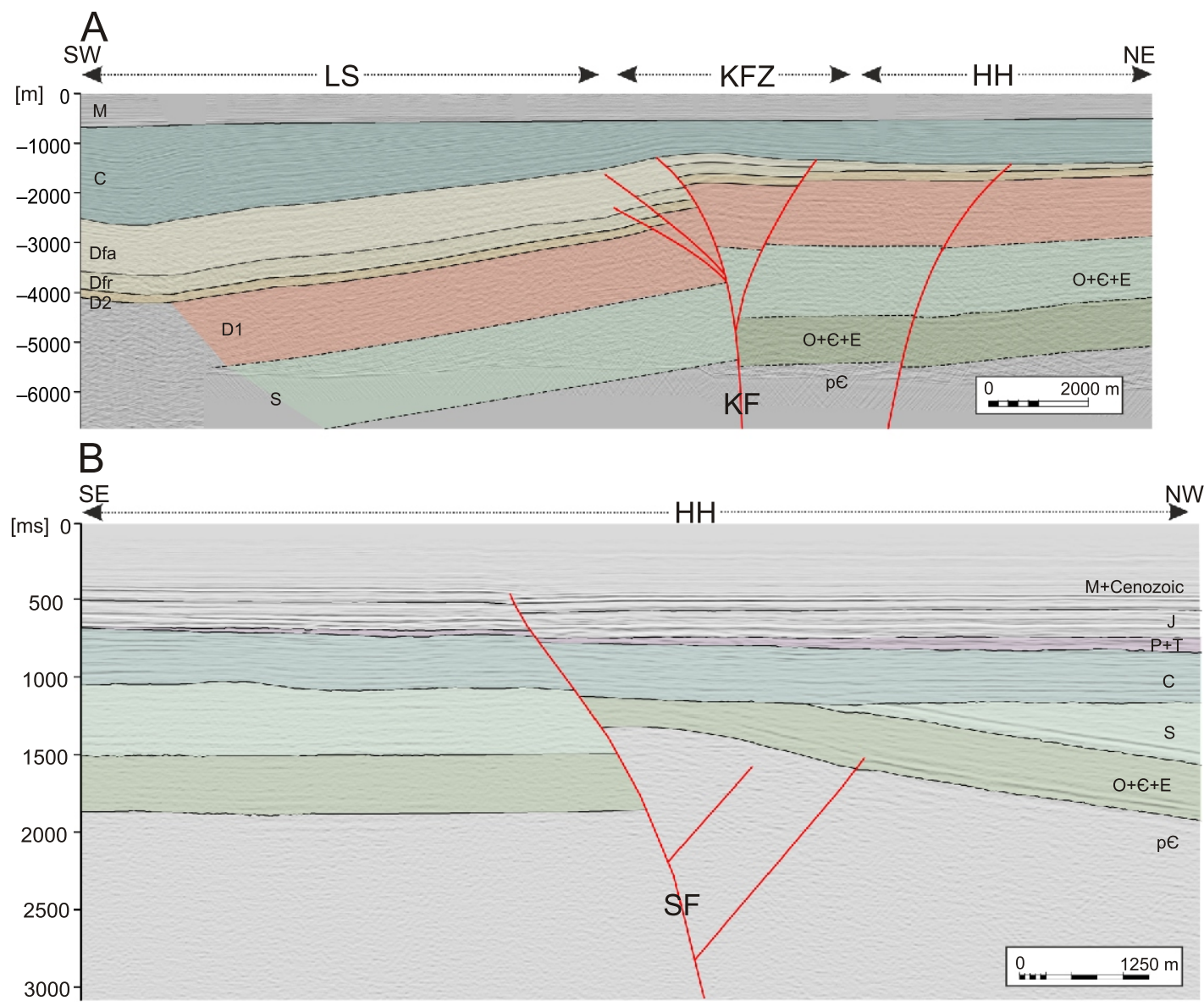

Fig. 8. Interpretation of seismic profiles across the Kock Fault Zone, KFZ (for location see Fig. 9)

A - part of regional seismic profile 7 from the eastern segment of KFZ, here, the Kock Fault is not overprinted by Kock Thrust deformations, thus no thickness changes of the Carboniferous complex across the Kock Fault are visible; B - seismic profile T0670197 from the Hrubieszów High, showing interpretation of the Siedliska Fault as a positive flower structure, note: seismic section $8 \mathrm{~B}$ is in time domain; explanations as in Figure 6

of the Kock Fault, while the low-angle thrusting was related to a younger-Late Carboniferous tectonic compression.

Reconstruction of pre-Carboniferous geometry of the Kock Fault is locally problematic because of high deformation level in the upper part of the Kock Fault, caused by the overprint by the Late Carboniferous thrusting and earlier erosion (described in the next section). Only in the SE flank of the KFZ, which is not affected by the Late Carboniferous thrusting, the reconstruction of the original pre-Carboniferous geometry of the Kock Fault is possible (Fig. 8A). Here, the Kock Fault is interpreted as a single steeply dipping inverted fault, in the lower part down to the crystalline basement, which, in the upper part, branches into a set of secondary faults, resembling positive flower-structure geometry (Mitra, 1993; Miller and Mitra, 2011). This complex Kock Fault structure records normal fault offset at the end of the Precambrian and Early Paleozoic, rather than its inversion with a contribution of a transpressive component. In the Pasmug boreholes area (Fig. 7B) the inverted fault preserves its original geometry. The range of reverse displacement at the Kock Fault exceeded the previous normal fault offset, which has led to its present-day reverse fault geometry with preserved steep dips of $60-70^{\circ}$ characteristic for normal faults.

\section{THE STRUCTURE OF THE KOCK THRUST}

Along almost the whole span of the KFZ, excluding its SE end, contractional structures are observed (Figs. 6 and 7). The most conspicuous of these structures is a major low-angle north-verging thrust fault called the Kock Thrust (Fig. 9). In the Lublin Synclinorium, the thrust becomes flat and is most probably detached within Silurian shales (Figs. 6 and 7). In the central segment of the KFZ, additional thrusts branch off the Kock Thrust's main sole thrust at its frontal part (Figs. 6A and 7). The thrust deformation zone in the Pasmug boreholes area reaches $7 \mathrm{~km}$ in width as measured at the bottom of the Zechstein (Fig. 7B). Along the whole KFZ, in the hanging wall of the Kock Thrust, at its frontal part, an asymmetric fault-propagation anticline was formed. The details of the internal geometry of this anticline are not well visible in the seismic sections due to high intensity of tectonic deformation in its core part. During the Late Carboniferous, the top part of the thrust-related anticline was eroded, thus in consequence, Devonian strata of various ages or Silurian ones became exposed in the core of the anticline (Figs. 6, 7 and 9). In our interpretation (Fig. 9), the narrow Silurian belt is the upper part of the Kock Fault being cut by the Kock Thrust and displaced northeastwards. The intense tectonic deformation within the anticline is caused primarily by a superposition of two tectonic compressional events, resulting in the Late Famennian inversion of the Kock Fault and the Late Carboniferous thin-skinned thrusting on the Kock Thrust. This can be noticed in the central part of the KFZ, in the Pasmug boreholes area, where Upper Devonian strata, dipping steeply due to the Late Famennian inversion of the Kock Fault, were subsequently involved in the Late Carboniferous thrusting (Fig. 7B). Here, the maximum displacement along the Kock Thrust is achieved and 


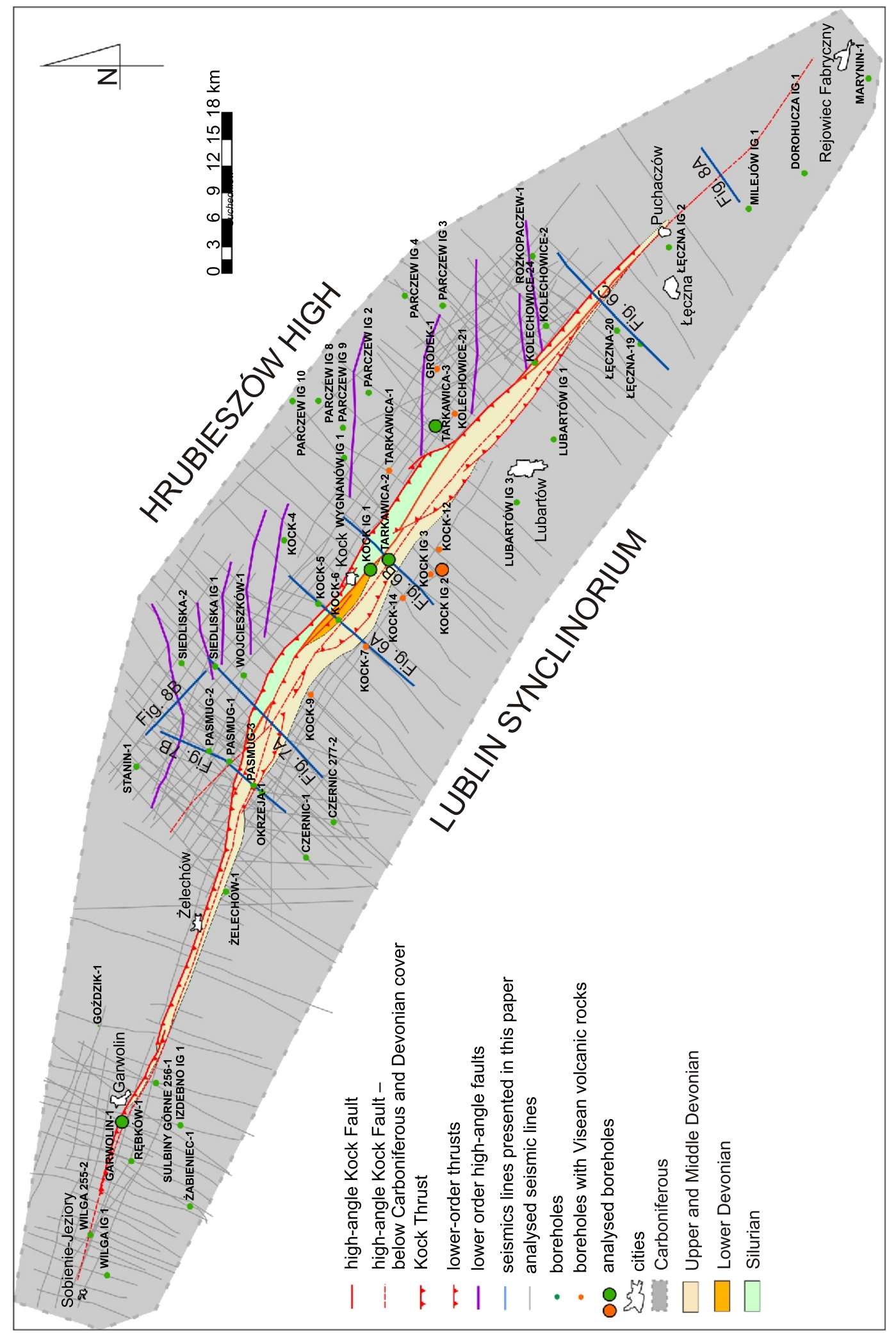

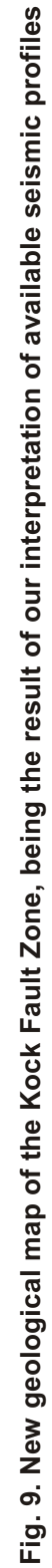


can be estimated at $3500 \mathrm{~m}$ (Fig. 7A). From there, the displacement magnitude gradually decreases along the strike towards the peripheral parts of the thrust. As confirmed by core observations (following section), contractional structures occasionally occur over a distance of a few kilometres from the main Kock Thrust fault, within its up to $6 \mathrm{~km}$ thick hanging wall, mostly in the shallower depth intervals, which are possibly related to lower-order, sub-seismic thrusts. Seismic sections from the NE limb of the Lublin Synclinorium show no evidence for deformational structures along the flat part of the Kock Thrust. This suggests that, provided our interpretation is correct, the thrust's flat segment is parallel to the layering and a low-friction décollement in shales produces a narrow shear zone. The footwall of the Kock Thrust, below and in front of the thrust, also acts as a SW limb of the Radzyń-Bogdanka-Chełm Syncline (Dembowski and Porzycki, 1988), which, as follows from the seismic sections (Figs. 6 and 7), was formed by gentle buckling in the course of the same thin-skinned deformation event. The contractional structures do not completely die out at the front of the Kock Thrust, but they continue towards the NE, predominantly in the Carboniferous complex, although also in the Lower Paleozoic section (Figs. 6B and 7B). This is also confirmed by structural analysis of core data from the Tarkawica-3 borehole (Fig. 10).

\section{STRUCTURAL ANALYSIS OF DRILL CORES}

Structural investigations of drill cores were performed in the Garwolin-1, Kock IG 2 and Tarkawica-3 boreholes drilled close to the KFZ, and in the Tarkawica-2 and Kock IG 1 boreholes within the KFZ (Fig. 9). The aim of this study was to check if the model constructed based on seismic data conforms to the meso-structural record in the rock samples. In particular, we have investigated the kinematics of fault offset, the succession of tectonic deformations, and the stress regime changes near the KFZ. A brief overview of tectonic observations in boreholes is presented below, starting from boreholes located south of the $\mathrm{KFZ}$, through those drilled within this zone, and finishing with that drilled north of the KFZ.

The Garwolin-1 borehole is located SW of the KFZ in its WNW segment (Fig. 9). The cored intervals cover $<20 \%$ of the $1000 \mathrm{~m}$ thick Lower Devonian through Carboniferous section (Fig. 10). In spite of the limited coring, a relatively large number of slickensides and minor faults were observed in this borehole. At a depth interval of 2831-2877 m, the Lower Devonian section is probably reduced by a normal fault. Between the Devonian and Carboniferous sections, a minor angular unconformity dipping at $5-10^{\circ}$ was noticed. Contractional structures of the thrust fault stress regime reach the borehole bottom at a depth of 2915 m, which may indicate occurrence of a larger-scale thrust below the borehole's terminal depth. Sparse steep calcite veins point to an extension of the Frasnian complex, approximately in the W-E direction, assuming the regional NW-SE direction strike of bedding planes. A single transtensional, left-lateral slickenside of unknown orientation was observed in the Carboniferous section.

The Kock IG 2 borehole is located close to the KFZ, in the south of its central segment (Fig. 9). Structural profiling was performed in the stratigraphic interval from Givetian to Westphalian, $>2400 \mathrm{~m}$ long. In the upper part of this interval, down to a depth of $2150 \mathrm{~m}$, coring covered $25 \%$ of the borehole section, while below this depth $\sim 50 \%$ (Fig. 11). An almost horizontal bedding position suggests little or no tectonic deformation. Indeed, the upper part of the borehole section reveals only a few small-scale thrust fault slickensides that allow hypothesizing the existence of a thrust fault somewhere at a depth of 1723-1740 m, in the Famennian complex. In the footwall of this thrust, only normal faulting slickensides were found, pointing to an extensional episode and lack of compressive stress regime. The abnormal geometry of the gently dipping normal fault slickensides can imply that the extension have taken place in a slightly compacted sediment, e.g. soon after the Famennian sedimentation. Of the same age can be a set of vertical veins in the bottom borehole interval, pointing to an extension in a direction transversal to the bedding strike. In spite of the better core coverage in this borehole in comparison to the Garwolin-1, the core inspection revealed much less thrust fault slickensides, which may result from a longer distance of this borehole from the KFZ.

The Tarkawica-2 borehole is located in the central segment of the KFZ (Fig. 9) and according to the seismic interpretation pierces the Kock Thrust (Fig. 6B). Structural investigations embraced all the cored intervals that covered altogether $<10 \%$ of the $3000 \mathrm{~m}$ long section of the Paleozoic complex, ranging from the Cambrian to the Famennian (Fig. 11). In the Devonian complex, at a depth $<1870 \mathrm{~m}$, there are only thrust fault stress regime structures, represented mainly by small-scale slickensides. The most intense thrust fault deformation with tilted bedding was observed at a depth $>1500 \mathrm{~m}$. Below a depth of 1880-2000 m, compressive deformations vanish almost completely, thus a thrust is expected below Lower Devonian marls. Due to long distances between the cored intervals, reaching $150 \mathrm{~m}$, the exact position of intense thrust deformations is not documented. Beneath a depth of $2650 \mathrm{~m}$, there are only extensional tectonic features, with normal fault slickensides in Silurian shales. In each case, a narrow zone of fault-related drag of strata suggests insignificant normal fault displacement. At the borehole bottom, below a depth of 3295 m, tectonic deformations are lacking, except for soft sediment disturbances that may point to seismic or tectonic instability during Cambrian deposition. Based on seismic interpretation, the Kock Thrust is located at the top of the complex with extensional slickensides (Figs. 6B and 11).

The Kock IG 1 borehole is located in the central segment of the KFZ (Fig. 9). The structural profiling was performed on a continuous $200 \mathrm{~m}$ long core interval of Silurian and Lower Devonian marls and shales (Fig. 10). The entire analysed profile is intensely tectonically deformed. The bedding is steep, dipping at $60-90^{\circ}$, including overturned position of strata, with the common thrust fault type of striation on polished bed surfaces (folding-related slip). Steep fault/shear zones cut the strata represented by a dense network of slickensides or cataclastic zones, tens of centimetres thick, which appear every several metres in the core profile. The faults show a strike-slip component with inconsistent sense of slip, and they are frequently accompanied by steep fracture cleavage. These faults frequently define an anastomosing pattern striking generally parallel to the steeply inclined bedding. Faults striking transversal to the bedding planes are subordinate. Integration of structural data from this well allows inferring the following sequence of tectonic events:

- Early stage of extension, indicated by calcite veins older than the fracture cleavage, may point to elongation in the direction transverse to the strike of bedding, which took place when the strata were in a horizontal or slightly tilted position.

- A stage of contraction, which led to steepening of beds, with top and base surfaces bearing dip-parallel striations (or slightly oblique). Gently dipping calcite veins, postdating the cleavage, might have been created at that time.

- A younger stage of selective strike-slip reactivation of the previous thrust fault slickensides mainly on steeply dipping bedding planes, with striations and fibrous min- 
Garwolin-1

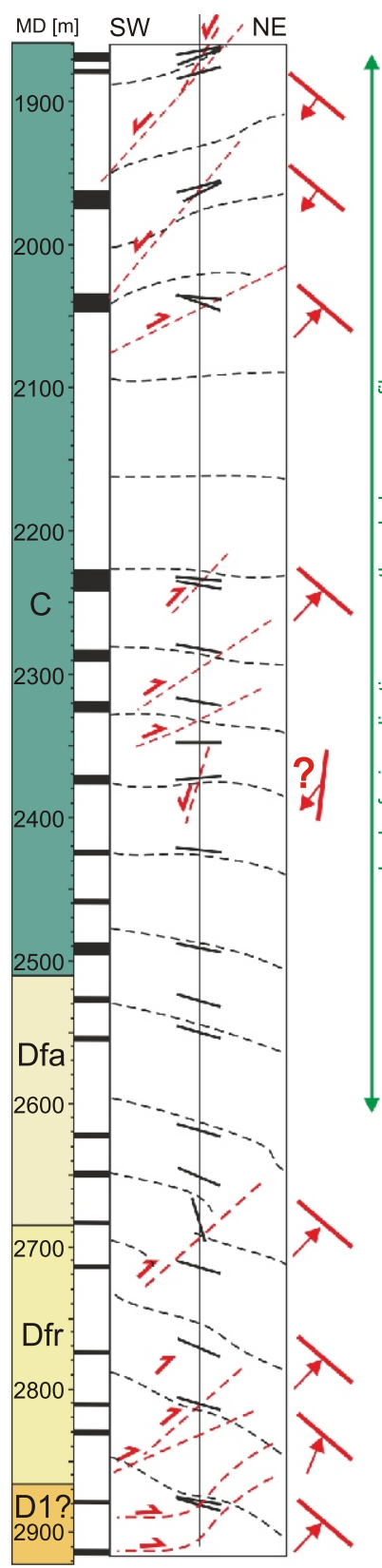

an a

\section{Kock IG 2}

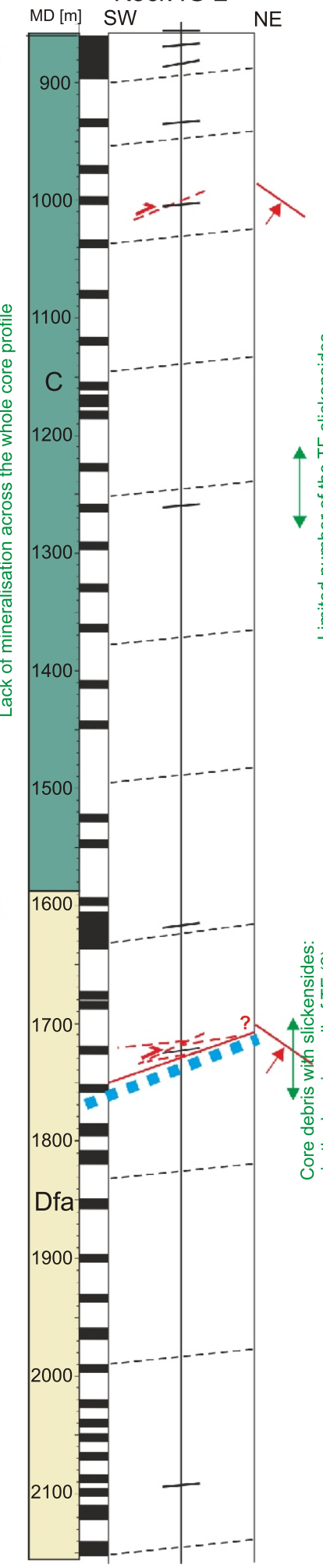

Symbols

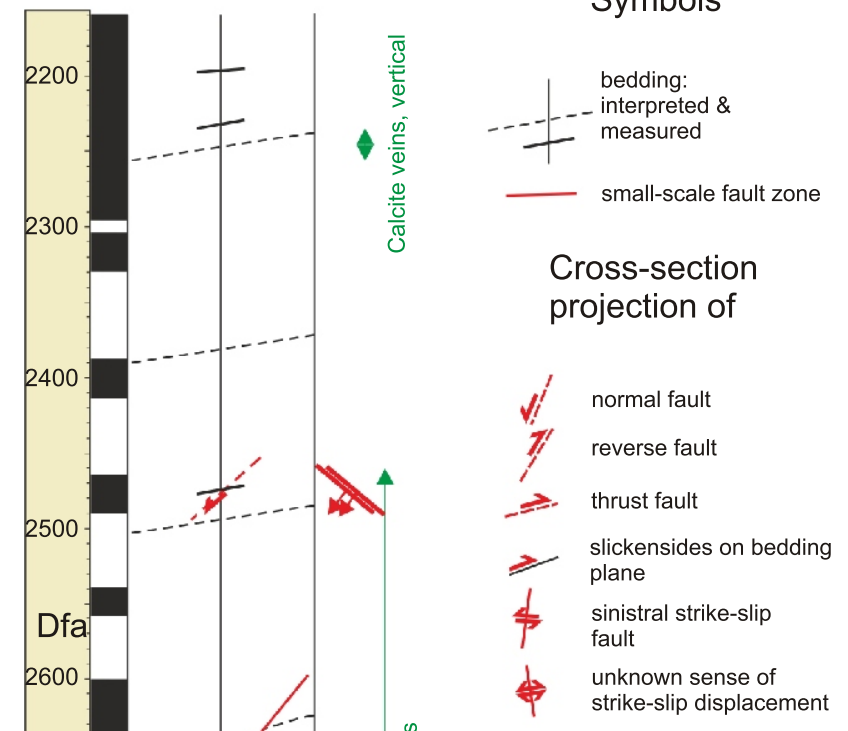

Orientation of faults in map view

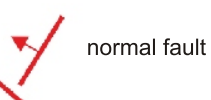

thrust fault

$\rightarrow$ reverse-oblique fault

oblique slip at bedding

plane

longitudinal dextral

strike-slip fault

unknown sense of

\$. strike-slip displacement

-........ fold hinge

14 conjugate joints

of strike-slip fault
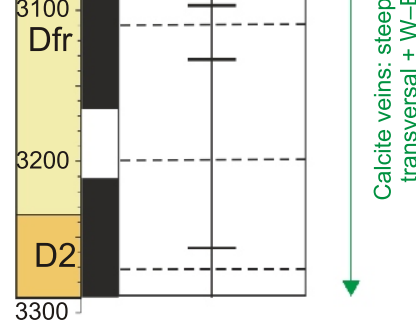

Kock Thrust according to seismic interpretation

possible thrust or bottom

of contractional zone

based on core data

MD - measured depth

Fig. 10. Tectonic profiles of boreholes, showing results of structural study of drill core from the Kock IG 2 and Garwolin-1 boreholes

Analysed core intervals marked by black stripes at the left-hand side of structural profile; other explanations as in Figure 6 
Tarkawica-2

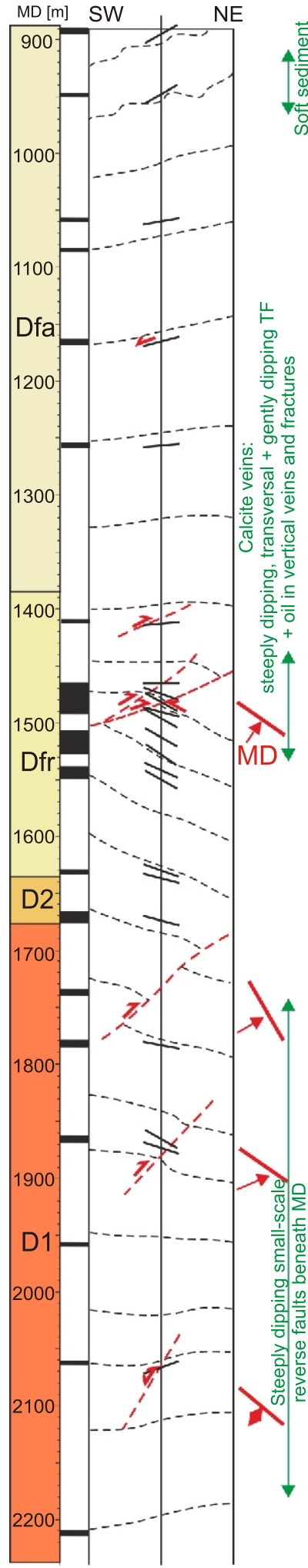

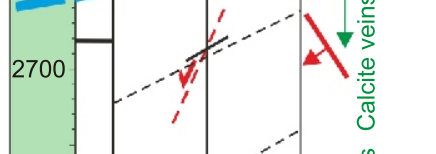

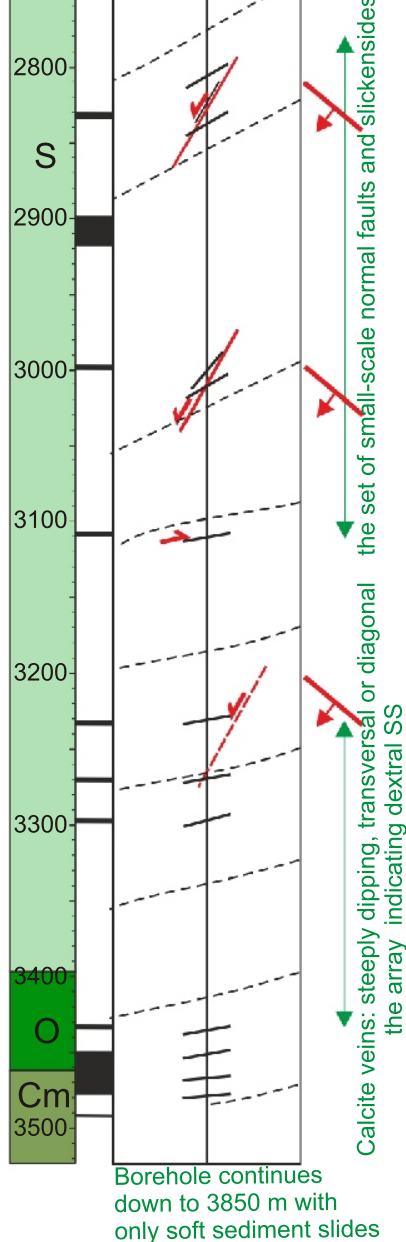

Tarkawica-3

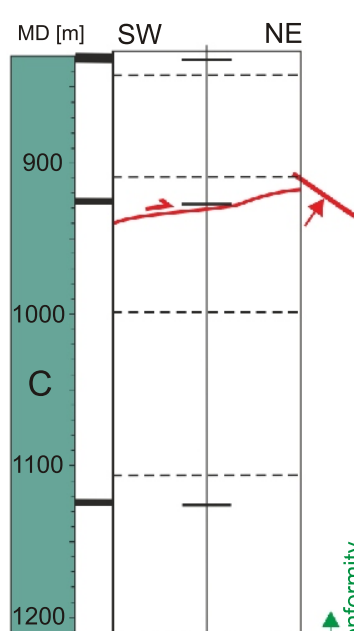

1200

Kock IG 1
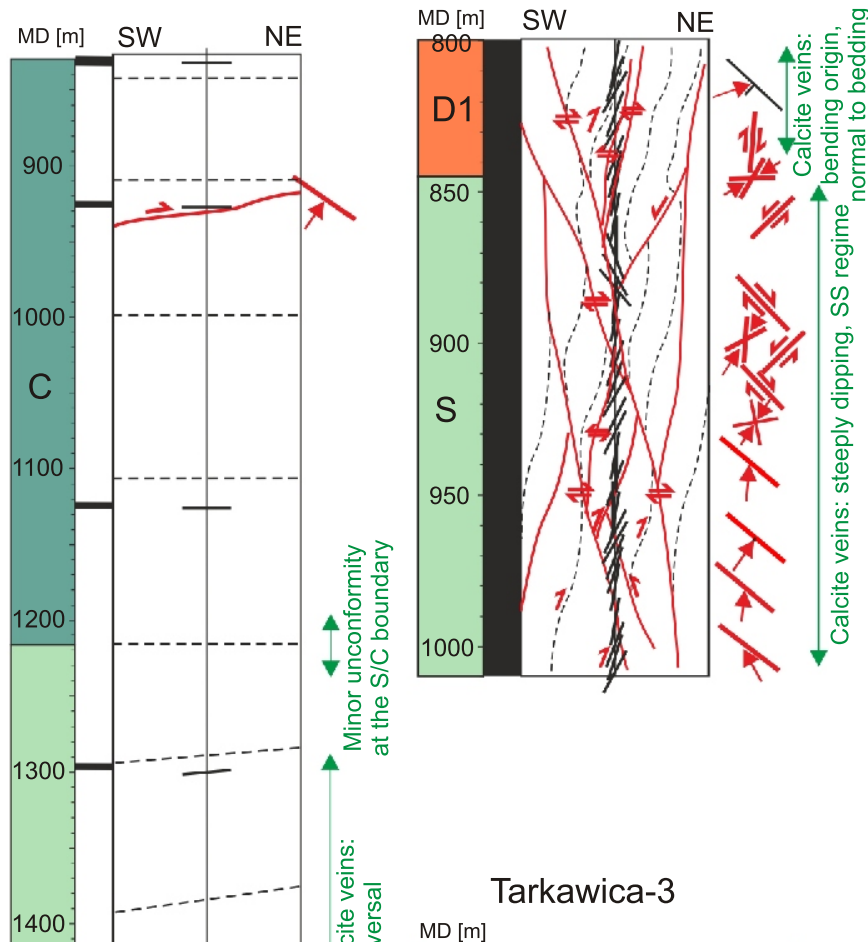

Tarkawica-3

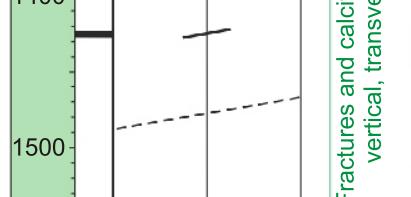

S
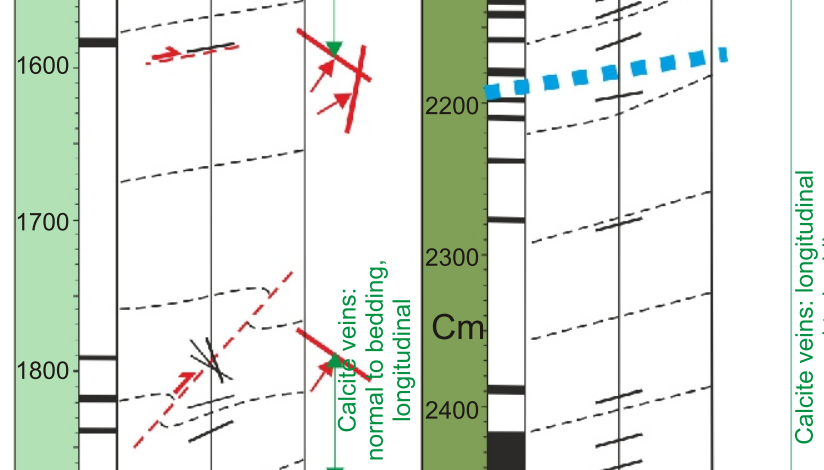

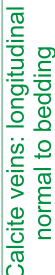

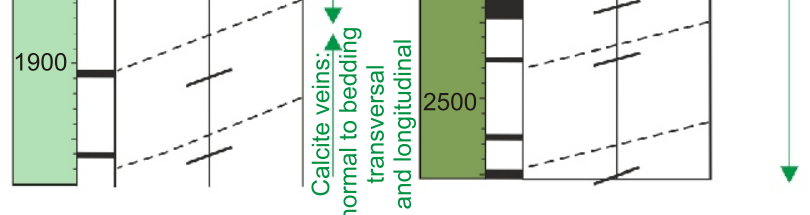

Fig. 11. Tectonic profiles of boreholes, showing results of structural study of drill core from the Tarkawica-2, Tarkawica-3 and Kock IG 1 boreholes

Explanations as in Figure 10 
erals indicating the right-lateral sense of shearing along the KFZ. This event might have taken place after the main compressive phase.

- Probably the youngest stage of deformation, represented by W-E-trending steep slickensides oblique to the strike of beds. The striation and mineralisation indicate the left-lateral sense of motion. The diagonal and transversal steep veins filled with pink calcite are associated with slickensides.

The Tarkawica-3 borehole is located $\mathrm{N}$ of the central segment of the KFZ (Fig. 9). The structural profiling was performed on core samples that cover $10 \%$ of the $2300 \mathrm{~m}$ long borehole section, spanning the Eocambrian through Carboniferous (Fig. 10). In this borehole, bedding planes dip at $5-20^{\circ}$ with the highest values controlled by early deformations of soft sediment or by fault drag in the hanging wall of the thrust fault, e.g. at a depth of $1790 \mathrm{~m}$. In general, two structural intervals can be distinguished in this borehole. In the upper one, down to a depth of $2088 \mathrm{~m}$, thrust fault slickensides prevail; however, steep calcite veins, transversal to the strike of beds, are also present. In the lower structural interval, below a depth of $2102 \mathrm{~m}$, contractional slickensides have not been found. Instead, a few normal-to-strata calcite veins indicate extension in a direction transversal to the strike of bedding planes. In this case, the bottom of the interval of contractional features at a depth close to $2150 \mathrm{~m}$ might not point to the thrust plain. However, it indicates a zone of thin-skinned contraction on the northern side of the KFZ.

\section{SUCCESSION OF DEFORMATIONS FROM BOREHOLE DATA}

Synsedimentary tectonic activity. The landslides and ductile folds that apparently developed in poorly consolidated sediments of the Upper Devonian sequence of the Tarkawica-2 borehole point to significant morphological gradients at the floor of the sedimentary basin. In case of marly facies, representative of a low-energy sedimentary environment, a tectonic factor triggering these perturbations is likely, and, therefore, reactivation of the nearby KFZ in the Late Devonian can be hypothesized.

Transverse and longitudinal extension. Extensional deformation took place in brittle, well-lithified rocks. Two sets of veins and small-scale faults can be identified to indicate two, mutually roughly perpendicular extension directions with respect to the strike of strata: transversal and longitudinal. Based on seismic interpretation, it is assumed that transversal structures strike $\sim \mathrm{NNE}-\mathrm{SSW}$, while the longitudinal ones in the WNW-ESE direction. The transverse extension is expressed by small-scale normal or normal oblique-slip faults trending parallel to the strike of bedding, which were observed in the Devonian and Silurian complexes of the Kock IG 2 and Tarkawica-2 boreholes. Transverse extension is also documented by the steep veins filled with calcite or with a quartz admixture, that were observed in the Kock IG 3, Tarkawica-2 and Tarkawica-3 boreholes. Longitudinal extension-produced steeply dipping or vertical veins, trending transverse to the strike of bedding, are common in the Kock IG 2, and subordinate in the Garwolin-1 borehole. Some calcite veins observed in the Upper Devonian complex are open with authigenic crystals at their walls that indicate low normal stress and probably shallow burial during mineralisation. Such conditions prevailed, e.g., during the Early Carboniferous erosional event. Normal faults have not been identified in the Carboniferous complex, except for a few ones in the Garwolin-1 borehole, not accompanied by mineralisation.

Compressive stress regime related to the main episode of thin-skinned thrusting. The gradual change from exten- sion to compression is reflected by widespread occurrence of a conjugate system of shear-origin joints perpendicular to bedding planes, which points to the pure shear mode of strain in a strike-slip stress regime that preceded the main thrusting phase. In the initial phase of thrusting, faults and slickensides developed in horizontal layers at low angles to bedding planes. A progress of contraction led locally to tilting of beds and formation of slickensides on the bedding surfaces. These first-order tectonic features are accompanied by small-scale folds and tectonic stylolites with rod lineation horizontal or gently dipping. In most cases, the striation is parallel or slightly oblique to the dip direction of slickensides, suggesting the primary failure in thrusting mode and a relatively stable stress direction while contraction. Thrust-related structures are present in the upper parts of borehole sections, which suggest the thin-skinned mode of thrusting.

Post-thrusting strike-slip regime. The thrust fault stress regime probably evolved gradually into the strike-slip one. This is evidenced by (steeply) dipping faults and slickensides with oblique or near-horizontal striation on their surfaces. Younger diagonal and conjugate slickensides with abundant mineralisation were observed in the Tarkawica-2, Kock IG 1, Tarkawica-1 and Tarkawica-3 boreholes. In turn, the right-lateral sense of shear, parallel to the strike of beds, was encountered in the Kock IG 1 and Tarkawica-1 boreholes. In Tarkawica-2, together with these younger stages of deformation the recrystallisation of dolomite, creation of voids and veins with oil shows was associated.

Among the investigated boreholes, the Kock IG 1 borehole located within the KFZ is specific. A steep, $200 \mathrm{~m}$ long zone of intense deformation shows several stages of thrusting to multi-stage strike-slip deformations. In the boreholes located south of the KFZ (Tarkawica-2 and Kock IG 2), below the complex with contraction-related structures, the only extensional structures are present within the Silurian and Famennian strata. This suggests that, before the thin-skinned contraction, the vicinity of the Kock Fault was dominated by normal faulting. Because these normal fault stress regime structures have not been noticed in the Carboniferous complex (except for a few in the Garwolin-1 borehole) the normal fault deformation might have taken place before deposition of the Carboniferous deposits.

In the Tarkawica-2 borehole, it was possible to compare the depth of seismically derived placement of the Kock Thrust with the structural profile, which coincides with the top of extensional domain, suggesting a very weak thrust plane. For the rest of the boreholes located on the southern side of KFZ, the seismically defined Kock Thrust passes below the borehole range. Thin-skinned contraction is not completely compensated within the KFZ, but extends further NE as far as the Tarkawica-1 and Tarkawica-3 boreholes, where the upper level of contractional features is also observed.

\section{STRUCTURAL EVOLUTION OF THE KOCK FAULT ZONE BASED ON SEISMIC AND CORE DATA}

The interpreted data constrain three major stages of the Paleozoic evolution of the KFZ (Fig. 13): (1) the oldest stage, related to the evolution of the Baltica margin in the Silurian (late Caledonian event); (2) the early Variscan stage at the turn of the Devonian and Carboniferous, related to the development of the Lublin Basin, and (3) the late Variscan stage in the Late Carboniferous, related to the final basin inversion. This tectonic deformation sequence was most probably preceded by the initiation of the Kock Fault at the turn of the Proterozoic and Paleo- 
zoic, which might be inferred from literature (Poprawa and Pacześna, 2002) reporting major tectonic activation of this region due to rifting and opening of the Tornquist Ocean. However, this oldest stage, which is not documented by the available seismic or borehole data, is rather hypothetical. The KFZ was also tectonically reactivated to a minor extent in both Mesozoic and most probably Cenozoic times. We mention it only briefly here, as these deformations have not exerted considerable impact on the Paleozoic complex structure.

\section{LATE CALEDONIAN STAGE}

Based on the increase of the thickness of Silurian strata in the NE hanging wall of the Kock Fault, it can be inferred that syndepositional activity of this fault began in the Ludlow (Fig. 7B). The extensional, normal fault kinematics of the Kock Fault might be related to the formation of the Caledonian foredeep on the subsiding margin of the East European Platform (Poprawa and Pacześna, 2002; Poprawa, 2006), which is typically governed by a slab pull mechanism of flexural plate bending. The highest thickness growth of the Silurian deposits, and therefore the maximum displacement at this fault, estimated at $2000 \mathrm{~m}$, can be noticed along the central part of the KFZ (Figs. 6, 7 and 12A).

\section{EARLY VARISCAN STAGE}

We have found no evidence of the Kock Fault activity in the Early and Middle Devonian. However, it cannot be definitely ruled out, as deposits of this age are almost completely eroded over the Hrubieszów High area in contrary to the Lublin Synclinorium where the Lower-Middle Devonian rocks are preserved (Fig. 9B, C). In some seismic sections from the NE limb of the Lublin Synclinorium, minor thickness changes are visible in the Frasnian in the close vicinity of the KFZ (Fig. 6A). This observation, reported also by other authors (Pelc, 1999; Krzywiec, 2009), is interpreted by us as the onset of syndepositional inversion of the KFZ. In the Late Famennian, the Kock Fault underwent inversion, initially in a compressive stress regime that subsequently turned into transpression. This idea is supported by the presence of a positive flower structure in the most SE segment of KFZ, where the original geometry of the Kock Fault, revealing an array of lower-order en echelon reverse faults in the Hrubieszów High, survived the overprint by younger deformations. Transpression along the Kock Fault can be inferred from space relation of the oblique fault array to the trend of the KFZ (Fig. 9). The most prominent secondary fault in the study area, the latitudinal Siedliska fault zone, located approximately $4 \mathrm{~km}$ $\mathrm{N}$ of the Pasmug-1 borehole (Figs. 7B and 8B), is also of positive flower structure geometry.

The onset of the Carboniferous sedimentation was associated with basaltic volcanism (Żelichowski, 1972, 1984; Depciuch, 1974; Żelichowski and Kozłowski, 1983; Grocholski and Ryka, 1995; Pańczyk and Nawrocki, 2015). Basalt caps and sills appear selectively in the vicinity of deep-rooted fault zones, of the Kock Fault in particular (Żelichowski and Kozłowski, 1983; Żelichowski, 1984). The age of the basaltic volcanism indicates that relaxation of the compressional (transpressional?) stress regime was replaced by tension (transtension?) after the Famennian. Abundant mineralisation described from cores from the Middle Devonian interval may be correlated with a massive migration of fluids, associated with this stage of intrusion (Fig. 12D).
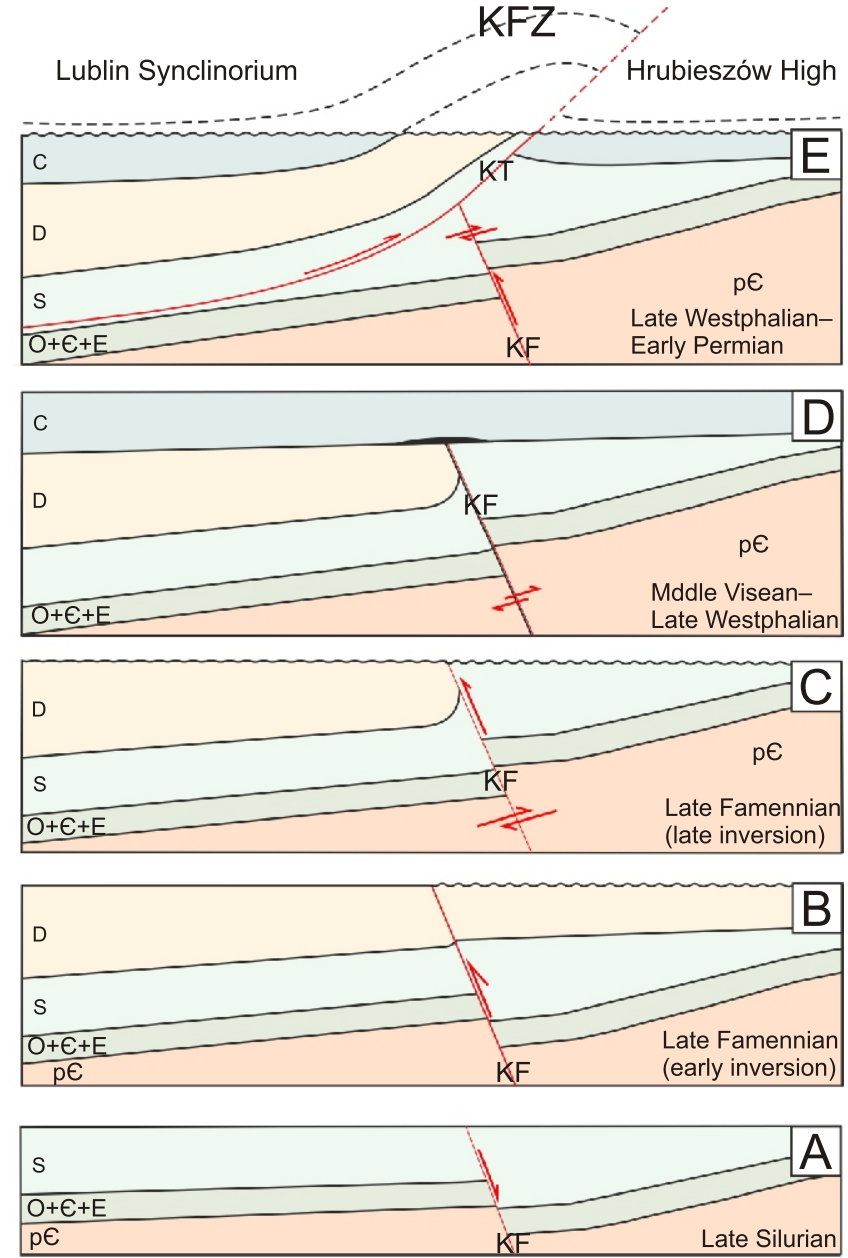

Fig. 12. Phases and geometry of tectonic deformations in the Kock Fault Zone based on palinspastic reconstruction of seismic profile T0060494

Explanations as in Figure 6

\section{LATE VARISCAN STAGE}

In post-Visean times during Carboniferous sedimentation, the Kock Fault was most probably not active. Our analysis confirms this opinion, as we have not found any changes in sediment thickness and seismic reflectors discontinuity, or any other manifestation of Late Carboniferous deformations above the Kock Fault (e.g., Fig. 8A), pointing to relaxed tectonic stresses. The cessation of Carboniferous deposition and initial late Variscan inversion of the Lublin Basin are dated to the Westphalian C or D (Narkiewicz et al., 2007; Narkiewicz, 2007).

Initially, inversion related to the SW-NE compression (Narkiewicz et al., 2007; Krzywiec, 2009) caused minor reactivation of the Kock Fault. It can be observed in the SE segment of the KFZ, where a small anticline developed just above the Kock Fault (Fig. 8A). In the other segments of the KFZ, this subtle Late Carboniferous inversion of the Kock Fault is not visible in the seismic sections, probably due to an overprint by younger deformations. However, it can be observed within the Carboniferous complex above the Siedliska Fault in an area not disturbed by the younger stage of thrusting (Fig. 7B), which is also mentioned 
by Krzywiec (2009). The initial stage of inversion of the Kock Fault may have been related to a thick-skinned contraction.

A further evolution of the collision zone caused a switch of deformation style to a thin-skinned thrusting that resulted in the development of the Kock Thrust. The location and orientation of this thrust were controlled by the scarp of the earlier Kock Fault, across which incompetent Silurian deposits of the Lublin Synclinorium were in contact with competent Cambrian rocks of the Hrubieszów High. Along the KFZ, the front of the Kock Thrust is located either next to the Kock Fault or cuts it through and moves its uppermost portion northeastwards. The thrust fault stress regime, related to the thin-skinned tectonic deformation, most likely turned into transpression at the final stage of contraction. This can be evidenced by the Kock IG 1 borehole core data, where low-angle thrusts interfere with younger high-angle strike-slip faults (Fig. 12E).

\section{DISCUSSION OVER TECTONIC CONCEPTS OF THE KOCK FAULT ZONE}

Our data and interpretation do not address the pre-Silurian evolution of KFZ due to the lack of borehole data and insufficient range of seismic record from the study area. The character of the deeply rooted fault suggests that it could develop in the very early stage of Ediacarian rifting, accompanied with volcanism in the Orsha-Volyn rift (Poprawa and Pacześna, 2002). A trend of this zone, which is parallel to the EEC, suggests that it can represent a set of faults associated with the formation of a triple junction developed at the edge of Baltica due to rifting of the Tornquist Ocean (Nawrocki and Poprawa, 2006). The positive seismic velocity anomaly in the lower and middle crust, interpreted from the Deep Seismic Sounding experiment (Guterch and Grad, 2006), can be related to the old magmatic activity in a rift trending close to the KFZ. The later Early Paleozoic evolution can be interpreted in terms of collision of Eastern Avalonia with the passive margin of Baltica. We postulate that normal faulting in the KFZ during the Silurian was controlled by a slab pull mechanism in front of the East Avalonia collision zone. The same mechanism can be responsible for the subsidence pattern in the area of the former Lublin Basin, which is typical of foredeep basins (Poprawa, 2006). The slab-pull is typically accompanied by extension, whose intensity depends on both the curvature of plate bending and the depth to the neutral surface within the plate. The Kock Fault appears to be an old tectonic zone that was extensionally reactivated in the pre-collision stage. In the proximity of the KFZ, no sign of Caledonian compression has been reported in this segment of the EEC. This indicates that either the KFZ was located away from the Caledonian collision zone or the zone was weak and detached in the Lublin Basin segment of Baltica.

Our observations do not confirm the deformation mechanism of the Silurian complex proposed by Pelc (1999) and Krzywiec (2007, 2009), who consider the geometry and complex internal structure of the KFZ to be a product of either a ductile flow of shale, creating a kind of shale diapir, or a ductile deformation driven by thin-skinned tectonics, called mushwad (Thomas, 2001), as proposed by Kufrasa and Krzywiec (2015) and Krzywiec et al. (2017). The drill core from the Kock IG 1 borehole provides evidence that the shale complex is cut by a dense network of slickensides that indicate a friction-controlled deformation. Therefore, from the mechanical point of view, it is not an unconsolidated soft rock ductile deformation, but a penetrative (even on a core scale) brittle deformation of well-consolidated shale. However, the macroscopic effect of both mecha-

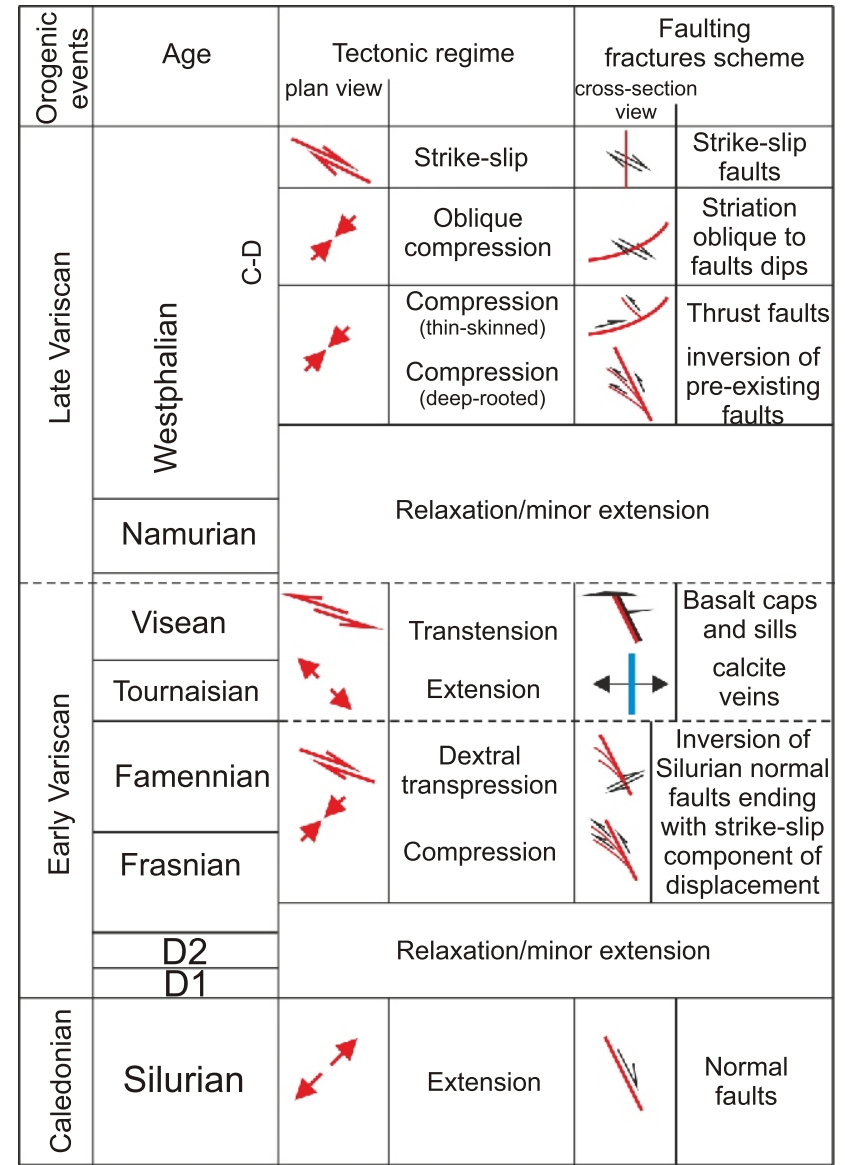

Fig. 13. Sequence of Paleozoic tectonic events in the Kock Fault Zone, associated stress regime, and the style of deformation changes inferred from this study

nisms of deformation could be similar on a seismic scale. The present-day geometry of the Silurian sequence can be explained by superposition of several tectonic episodes described in our paper. Local thickness reduction of the Upper Devonian sequence in the SW part of the KFZ, described by Krzywiec (2007) as an indication of an early phase of growth of quasi-diapric structures, is related in our interpretation to the development of an anticline above the Kock Fault due to its inversion. The first indication of thickness difference in the upper Devonian comes from the Frasnian section. The interpretation of Silurian shale diapirs on seismic sections published by Pelc (1999) and Krzywiec $(2007,2009)$ may arise from lower quality of seismic data in comparison to these available to us.

Until now, the Late Devonian subsidence of the Lublin Basin was explained by a transtensional mechanism, in which the KFZ played a role of an active strike-slip fault (Narkiewicz et al., 1998, 2007; Narkiewicz, 2007). This stands in contradiction with our concept, according to which the inversion of the Kock Fault in the Late Devonian occurred in a compressive stress regime. It implies that the Lublin Basin subsidence should have had the same compressional origin at that time. A more precise description of this phenomenon is out of the scope of this paper.

In our interpretation, the Late Devonian/Early Carboniferous fault pattern in the Hrubieszów High (Fig. 3) differs significantly from that on previously published geological maps (Żelichowski, 1972; Żelichowski and Kozłowski, 1983; Pożaryski and Dembowski, 1983). On these maps the major faults are oriented SW-NE, whereas our seismic data indicate 
dominant E-W fault trends. In the Hrubieszów High area corresponding to the central segment of KFZ, the latitudinal faults can be clearly inferred from seismic data, while in the rest of the block, our interpretation is not so unequivocal. The orientation of these faults is important for understanding the remote, continental-scale tectonic controls on the structural style of Late Devonian/Early Carboniferous deformation.

Previous publications regarding the Late Devonian/Early Carboniferous deformations in the KFZ suggested a large-scale displacement along vertical faults (Żelichowski, 1972; Żelichowski and Kozłowski, 1983), which did not explain the actual kinematics and stress regime control on the deformations. In our opinion, the onset of Late Devonian deformations is related to a compressive stress regime with a dextral transpression component, which is responsible for inversion of the Kock Fault and uplift of tectonic blocks on the Hrubieszów High. The compression started probably in the Late Frasnian and continued until earliest Carboniferous times. Subsequently, during the Visean, the compressive stress relaxed and gave way to eruption of basaltic igneous rocks, indicative of a tensional stress regime. Therefore, we postulate that the stress regime changed from compression to tension in the earliest Carboniferous, before the end of the Visean. The extension might have been enhanced by a hot spot responsible, according to Narkiewicz (2007), for the magmatic activity in the Lublin Basin at that time, as well as for the earlier magmatic event in the Pripyat graben.

There is still an open question concerning the tectonic reactivation of the KFZ during deposition of the Carboniferous basin fill. A pull-apart transtensional subsidence mechanism was suggested for the Lublin Basin (Narkiewicz et al., 1998; Krzywiec and Narkiewicz, 2003; Narkiewicz, 2007) that led to a synsedimentary reactivation of the KFZ (Narkiewicz, 2003, 2007). The role of the KFZ during the Carboniferous sedimentation is obliterated by the Late Carboniferous thin-skinned tectonic overprint. Nevertheless, based on interpretation of the exhaustive set of seismic data, it can be concluded that there is no evidence for the synsedimentary KFZ displacement at that time. Even in the areas that underwent minor overprint by the Kock Thrust, the thickness difference in the Carboniferous complex across the Kock Fault is unnoticeable (Fig. 8A). Some authors (Krzywiec and Narkiewicz, 2003) explained the absence of fault displacement by inversion that might have compensated an initial offset. In our opinion, such a scenario is unlikely, taking into account both the length of the Kock Fault and the fact that there is no thickness contrast in the Carboniferous deposits all across the fault.

The present-day structure of KFZ has been shaped to a major extent by the Late Carboniferous thin-skinned overthrusting. The older structures were inverted or cross-cut and displaced by thrust faults. From our interpretation, the maximum dip-slip offset on the Kock Thrust is estimated at $3.5 \mathrm{~km}$ in the central segment of KFZ. It implies a similar or greater offset along the continuation of this thrust beneath the Lublin Synclinorium. Looking for the preferential detachment horizon, we point to the Silurian shale sequence as a mechanically weaker suitable candidate for a regional detachment.

Thrusting-related structures were observed on core samples from all the analysed boreholes. The contractional structures occur systematically in the uppermost parts of the Paleozoic profiles, while in the lower sections, which, according to seismic interpretation, are still placed within the hanging wall of the Kock Thrust, only extensional structures are observed Hence, it seems that penetrative contractional deformations affected only some of the upper levels of the thrusted complex, while the remaining part was hidden in the compression shadow. Due to the scarcity or absence of contractional structures over long borehole intervals of the thrusted complex, we expect the Silurian detachment surface to be mechanically very weak, and the thin-skinned thrusting can be distributed on several minor thrusts of the scale below seismic resolution. There is also possibility that displacement on the Kock Thrust is lower than suggested by palinspastic reconstruction in this study. The calculated thrusting distance could originate from integration of thin-skinned thrusting with deep-rooted, younger, transpressive deformations, whose influence cannot be taken into account in our interpretation. The quality of available data and the limited range of the study area do not allow providing a definite answer to the problem of the regional detachment level and its displacement. Hereby, we only highlight the problem that should be addressed in a broader context.

A thin-skinned thrusting in the Lublin Basin in Carboniferous times was previously proposed by Antonowicz et al. (2003) and Antonowicz and Iwanowska (2004), by analogy to the context of the Appalachian foredeep basin (Mitra, 1988; Keller and Hatcher, 1999). These authors suggested that the KFZ represents an accommodation zone of a thin-skinned thrust sheet, which decouples the Lublin Basin fill from its basement. In this concept, the Upper Paleozoic complex forms a passive syncline over one or two flat decollement levels, one in the Lower Paleozoic and the second in the Lower Devonian sequence. Antonowicz et al. (2003) and Antonowicz and Iwanowska (2004) assumed a significant thrust displacement within the KFZ. Depending on the publication, they propose either $>10 \mathrm{~km}$ displacement compensated by a duplex structure within the KFZ (Antonowicz et al., 2003) or $\sim 5 \mathrm{~km}$ displacement on a single thrust (Antonowicz and Iwanowska, 2004). Our interpretation conforms to the general concept of thin-skinned thrusting of the Upper Paleozoic infill of the Lublin Synclinorium; however, the scale of tectonic transport, proposed by us, is significantly lower and the duplex geometry of the KFZ is not confirmed. We also emphasize a multiphase, protracted evolution of the KFZ in varying tectonic stress regimes that led to its complex present-day structure.

In both the seismic profiles and borehole core samples, we have observed deformations of compressive origin extending farther northward from the KFZ, shaped as minor buckling folds on the seismic scale, and small-scale thrust fault slickensides visible in the drill core. Their minor scale, thin-skinned character, and northward-decreasing trend suggest that the KFZ is the front of significant Variscan contractional deformations. As it is located several hundred kilometres from the direct collision zone between tectonic plates, which is proven in the Sudetes, we can expect that the late Carboniferous collision phase had a coupled character and the thin-skinned thrust faults penetrate far to the foreland plate beyond the range of flysch sediments.

\section{SUMMARY}

We have described the results of tectonic interpretation of a number of seismic sections and core samples from the vicinity of the Kock Fault Zone (KFZ), which is a major discontinuity in the Lublin Basin. It separated the Late Paleozoic depocentre located in the Lublin Synclinorium from the NE marginal part of the basin called the Hrubieszów High. Although this fault zone has drawn attention of several generations of geologists, there is still lack of a genetically and kinematically consistent concept of its evolution. Deciphering the tectonic evolution of this zone brings us closer to understanding the evolution of the whole Lublin Basin. 
The first structural record in the KFZ comes from the Late Silurian, when the older precursor of this zone, namely the normal Kock Fault, differentiated the thickness of Silurian deposits up to $2000 \mathrm{~m}$ in the central part of the KFZ. We link this extensional phase with the formation of the Caledonian foredeep at the margin of the East European Craton. In the Late Famennian, the Kock Fault underwent inversion, probably in a transpressive stress regime, which resulted in erosion of more than $2000 \mathrm{~m}$ of Devonian and partly Silurian deposits on the Hrubieszów High. At the beginning of the Carboniferous, the major basaltic intrusion stage along the Kock Fault points to activation of deeply rooted source of magma in a tensional (or transtensional) stress regime. We infer from the above that the stress field evolved from an initial compression to the final tension during the Late Devonian-Early Carboniferous tectonic phase. During the Carboniferous stage of the Lublin Basin subsidence, the Kock Fault was probably inactive.

The initial stage of the Late Carboniferous (Westphalian) contraction on the Kock Fault might have been related to a deeply rooted compression that led to its minor inversion. Later on, the compression turned from deep-rooted to thin-skinned, resulting in the formation of the Kock Thrust. The location and orientation of this thrust was controlled by the Kock Fault step across which incompetent Silurian deposits of the Lublin Synclinorium contact with competent elevated Cambrian rocks of the Hrubieszów High that create kind of buttress. The Kock Thrust breached the steeply dipping Kock Fault and displaced its upper part northeastwards, causing also minor folding of the shallow sedimentary cover in the Hrubieszów High. Palinspastic reconstruction indicates the thin-skinned thrust fault displacement in a range exceeding $3 \mathrm{~km}$. A successive minor transpressive event, followed by relaxation and extension of fracture network combined with mineralization, ended the Paleozoic history of the KFZ.

Acknowledgements. The authors would like to thank the Polish Oil and Gas Co., which is the owner of part of seismic and drillcore data presented in the paper, for their approval to publish them. We also appreciate the partial financial support granted by the Polish Geological Institute - NRI from the funds of the Ministry of Science and High Education. We are indebted to three reviewers: P. Aleksandrowski, A. Konon and $Ł$. Gągała, whose valuable comments and text correction were gratefully used in order to improve the final version of this paper.

\section{REFERENCES}

Aleksandrowski, P., Buła, Z., 2017. Late Paleoozoic structures (Variscan) (in Polish). In: Geologiczny Atlas Polski (eds. J. Nawrocki and A. Becker). Państwowy Instytut Geologiczny PIB, Warszawa.

Antonowicz, L., Iwanowska, E., 2004. Thin-skin nature of the Variscan tectonics in the Lublin area, Poland (in Polish with English summary). Przegląd Geologiczny, 52: 128-130.

Antonowicz, L., Hooper, R., Iwanowska, E., 2003. Lublin Syncline as a result of thin-skinned Variscan deformation (SE Poland) (in Polish with English summary). Przegląd Geologiczny, 51: 344-350.

Brochwicz-Lewiński, W., Pożaryski, W., Tomczyk, H., 1981. Large-scale strike-slip movements along SW margin of the East-European platform in the early Paleozoic (in Polish with English summary). Przegląd Geologiczny, 29: 385-397.

Dembowski, Z., Porzycki, J., eds., 1988. Carboniferous of the Lublin Coal Basin (in Polish with English summary). Prace Instytutu Geologicznego, 122

Depciuch, T., 1974. Geochronological investigations of the magmatic rocks (in Polish with English summary). Prace Instytutu Geologicznego, 74: 81-83.

Grocholski, A., Ryka, W., 1995. Carboniferous magmatism of Poland. Prace Państwowego Instytutu Geologicznego, 148: 181-189.

Guterch, A., Grad, M., 2006. Lithospheric structure of the TESZ in Poland based on modern seismic experiments. Geological Quarterly, 50 (1): 22-32.

Keller, G.R., Hatcher, Jr.R.D., 1999. Some comparison of structure and evolution of the Southern Appalachian-Ouachita orogeny and portions of the trans-European Suture Zone region. Tectonophysics, 314: 43-68.

Królikowski, C., Petecki, Z., 1995. Gravimetric Atlas of Poland. Polish Geological Institute, Warszawa.

Krzywiec, P., 2007. Tectonics of the Lublin area (SE Poland) - new views based on result of seismic data interpretation (in Polish with English summary). Biuletyn Państwowego Instytutu Geologicznego, 422: 1-18.
Krzywiec, P., 2009. Devonian-Cretaceous subsidence and uplift along the Teisseyre-Tornquist zone in SE Poland - insight from seismic data interpretation. Tectonophysics, 475: 142-159.

Krzywiec, P., 2011. Interpretacja tektoniczna profilu sejsmicznego T0690481 w rejonie otworu wiertniczego Parczew IG-10 (in Polish). Profile Głębokich Otworów Wiertniczych Państwowego Instytutu Geologicznego, 130: 145-146.

Krzywiec, P., Narkiewicz, M., 2003. O stylu strukturalnym kompleksu dewońsko-karbońskiego Lubelszczyzny w oparciu o wyniki interpretacji danych sejsmicznych. Przegląd Geologiczny, 51: 795-797.

Krzywiec, P., Mazur, S., Gagała, Ł., Kufrasa, M., Lewandowski, M., Malinowski, M., Buffenmyer, V., 2017. Late Carboniferous thin-skinned compressional deformation above the SW edge of the East European Craton as revealed by reflection seismic and potential fields data - correlations with the Variscides and the Appalachians. GSA Memoir, 213, DOI: 10.1130/2017.2013(14).

Kufrasa, M., Krzywiec, P., 2015. New structural model of the Kock Fault Zone (Lublin Basin, SE Poland). CETEG-Kadań, conference abstract. University of Praque.

Lewandowski, M., 1992. Palaeomagnetic constraints for Variscan mobilism of the Upper Silesian and Malopolska Massifs, southern Poland. Geological Quarterly, 38 (2): 211- 230.

Miller, J.F., Mitra, S., 2011. Deformation and secondary faulting associated with basement-involved compressional and extensional structures. AAPG Bulletin, 95: 675-689.

Miłaczewski, L., Żelichowski, A.M., 1968. Niektóre zagadnienia stratygrafii i tektoniki dewonu oraz karbonu na Lubelszczyźnie (in Polish). Kwartalnik Geologiczny, 12 (2): 423-424.

Mitra, S., 1988. Three-dimensional geometry and kinematic evolution of the Pine Mountain thrust system, southern Appalachians. GSA Bulletin, 100: 72-95.

Mitra, S., 1993. Geometry and kinematic evolution of inversion structures. AAPG Bulletin, 77: 1159-1191.

Narkiewicz, M., 2003. Tectonic controls of the Lublin Graben (Late Devonian - Carboniferous) (in Polish with English summary). Przegląd Geologiczny, 51: 771-776. 
Narkiewicz, M., 2007. Development and inversion of Devonian and Carboniferous basins in the eastern part of the Variscan foreland (Poland). Geological Quarterly, 51 (3): 231-256.

Narkiewicz, M., 2011. Lithostratigraphy, depositional systems and transgressive-regressive cycles in the Devonian of the Lublin Basin (south-eastern Poland) (in Polish with English summary) Prace Państwowego Instytutu Geologicznego, 196: 53-101.

Narkiewicz, M., Dadlez, R., 2008. Geological regional subdivision of Poland: general guidelines and proposed schemes of sub-Cenozoic and sub-Permian units (in Polish with English summary). Przegląd Geologiczny, 56: 391-397.

Narkiewicz, M., Poprawa, P., Lipiec, M., Matyja, H., Miłaczewski, L., 1998. Paleogeographic and tectonic settings and the Carboniferous subsidence development of the Pomerania and Radom-Lublin areas (TESZ, Poland) (in Polish with English summary). Prace Państwowego Instytutu Geologicznego, 165 31-49.

Narkiewicz, M., Jarosiński, P., Krzywiec, P., Waksmundzka, M., 2007. Regional controls on the Lublin Basin development and inversion in the Devonian and Carboniferous (in Polish with English summary). Biuletyn Państwowego Instytutu Geologicznego, 422: 19-34.

Narkiewicz, M., Maksym, A., Malinowski, M., Grad, M., Guterch, A., Petecki, Z., Probulski, J., Janik, T., Majdański, M., Środa P., Czuba, W., Gaczyński, E., Jankowski, L., 2015 Transcurrent nature of the Teisseyre-tornquist Zone in Centra Europe: result of the POLCRUST-01 deep reflection seismic profile. International Journal of Earth Sciences, 104: 775-796.

Nawrocki, J., Poprawa, P., 2006. Development of Trans-European Suture Zone in Poland: from Ediacaran rifting to Early Paleozoic accretion. Geological Quarterly, 50 (1): 59-76.

Ostrowski, C., Musiatewicz, M., 1996. Dokumentacja z interpretacji pomiarów grawimetrycznych, temat: Rów Mazowiecko-Lubelski, rejon: Maciejowice-Abramów (in Polish). Opr/G/1910, PGNiG Geological Database.

Pacześna, J., 2006. Evolution of the late Neoproterozoic-Early Cambrian rift depocentres and facies in the Lublin-Podlasie sedimentary basin (in Polish with English summary). Prace Państwowego Instytutu Geologicznego, 186: 9-37.

Pacześna, J., 2010. Lithofacies-paleothicknesess maps of Cambrian In: Paleogeological Atlas of the sub-Permian Paleozoic of the East-European Craton in Poland and Neighboring Areas (ed. Z. Modliński). Państwowy Instytut Geologiczny, Warszawa.
Pańczyk, M., Nawrocki, J., 2015. Tournaisian ${ }^{40} \mathrm{Ar} /{ }^{39} \mathrm{Ar}$ age for alkaline basalts from the Lublin Basin (SE Poland). Geological Quarterly, 59 (3): 473-478.

Pelc, T., 1999. Dewońsko-karboński diapiryzm sylurskich osadów ilastych basenu lubelskiego (in Polish). V Konferencja Naukowo-Techniczna "Geofizyka w geologii, górnictwie i ochronie środowiska”. Kraków, 137-142.

Poprawa, P., 2006. Development of the Caledonian collision zone along the western margin of Baltica and its relation to the foreland basin (in Polish with English summary). Prace Państwowego Instytutu Geologicznego, 186: 189-213.

Poprawa, P., Pacześna, J., 2002. Late Neoproterozoic to Early Paleozoic development of a rift at the Lublin-Podlasie slope of the East European Craton - analysis of subsidence and facies record (in Polish with English summary). Przegląd Geologiczny, 50: 49-61.

Pożaryski, W., Dembowski, Z., eds., 1983. Mapa geologiczna Polski i krajów ościennych bez utworów kenozoicznych, mezozoicznych i permskich. 1:1000 000. Instytut Geologiczny, Warszawa.

Pożaryski, W., Tomczyk, H., 1993. Geological cross-section through SE Poland (in Polish with English summary). Przegląd Geologiczny, 48: 65-76.

Thomas, W.A., 2001. Mushwad: ductile duplex in the Appalachian thrust belt in Alabama. AAPG Bulletin, 85: 1847-1869.

Wójcicki, A., Kleszcz, T., Lisowski, K., 1998. Dokumentacja z interpretacji pomiarów grawimetrycznych w rejonie synklinorium lubelskiego z uwzględnieniem wyników prac wykonanych w 1997 r. na temacie Łuków-Kock (półszczegółowe zdjęcie grawimetryczne Radom-Lublin 1997), rejon: Łuków-KockBełżyce (in Polish). Opr/G/476, PGNiG Geological Database.

Żelichowski, A.M., 1972. Evolution of the geological structure of the area between the Holy Cross mountains and the river Bug (in Polish with English summary). Biuletyn Instytutu Geologicznego, 263: 7-97.

Żelichowski, A.M., 1984. Tektonika lubelskiego zagłębia węglowego (in Polish). In: Przewodnik LVI zjazdu PTG Lublin (ed. M. Harasimiuk). Wyd. Geol., Warszawa.

Żelichowski, A.M., Kozłowski, S., eds., 1983. Atlas geologicznosurowcowy obszaru lubelskiego. Wyd. Geol., Warszawa. 